\title{
JOÃO MULUNGU: A INVENÇÃO DE UM HERÓI AFRO-BRASILEIRO
}

\author{
João Mulungu: creating an African-Brazilian hero \\ Petrônio Domingues*
}

Dizer que os quilombolas foram heróis é pouco, pois diminui a riqueza de sua experiência. Que sejam celebrados como heróis da liberdade.

\begin{abstract}
RESUMO
$\mathrm{O}$ artigo tem a finalidade de investigar o processo de construção de um herói afro-brasileiro. Sua questão central é saber como João Mulungu - considerado o mais notável líder quilombola de Sergipe na segunda metade do século XIX - foi revalorizado nos domínios da memória por parte de setores do movimento negro nas décadas de 1980 e 1990 e promovido à condição de primeiro herói negro do estado reconhecido oficialmente. Esta representação de João Mulungu não deve ser vista tão somente como uma falsa verdade, mas sim ressignificação da memória, fenômeno social que faz parte do processo histórico.
\end{abstract}

Palavras-chave: negro; raça; politização da memória.

\begin{abstract}
The aim of the current study is to investigate the process of creating an African-Brazilian hero. Its central point lies in getting to know how João Mulungu - who was considered the most

* Doutor em História (USP). Professor da Universidade Federal de Sergipe (UFS).

1 REIS, João José e GOMES, Flávio dos Santos. "Uma história da liberdade". In: REIS, João José e GOMES, Flávio dos Santos (orgs.). Liberdade por um fio: história dos quilombos no Brasil. São Paulo: Companhia das Letras, 1996, p. 23.
\end{abstract} Pesquisador do CNPq. 
remarkable quilombola leader of Sergipe State in the second half of the nineteenth century - was extolled in the domains of historical memory by sectors of the black movement in the 1980 s and $1990 \mathrm{~s}$ and exalted to the status of first officially acknowledged African-Brazilian hero of Sergipe. Such representation of João Mulungu should not be seen just as a false truth, but as the process of giving a new meaning to the historical memory, as a social phenomenon that is part of the historical process.

Keywords: African-Brazilian; race; memory politicization.

Em novembro de 2007, o Núcleo de Estudos Afro-Brasileiros da Universidade Federal de Sergipe (UFS) promoveu a IV Semana da Consciência negra, evento que reuniu palestras, mesas de debates, minicursos, enfim, acomodou uma serie de atividades acadêmicas para discutir questões raciais, políticas públicas e ações afirmativas. No segundo dia do evento, houve a palestra de José Severo dos Santos, mais conhecido pelo cognome Severo D'Acelino, o fundador e presidente da Casa de Cultura Afro-Sergipana, que abordou alguns aspectos dos dilemas e desafios da questão racial no estado. Tinha, há pouco, chegado do Paraná, onde residia, e me tornado professor adjunto do Departamento de História da UFS. Embora fosse um pesquisador da temática, conhecia pouco os termos desse debate em Sergipe, daí minha curiosidade para ver a palestra do D'Acelino. Como típica liderança do movimento negro, este denunciou o "mito da democracia racial" $" 2$ no estado e centrou a sua narrativa em torno da luta do negro e suas formas de resistência desde a época da escravidão. Entre outros fatos e personagens, ele evocou $o$ protagonismo de dois ícones afro-sergipanos: Quintino de Lacerda e João Mulungu. Talvez convenha abrir um parêntese.

Quintino de Lacerda era um negro, que nasceu na condição escrava em Itabaiana, cidade do agreste sergipano, em 1855. Fez parte do tráfico interprovincial, sendo vendido por volta dos 19 anos para São Paulo, onde se tornou "escravo de ganho" de Antônio de Lacerda

2 Sobre o "mito da democracia racial", com sua história, seus diferentes significados e implicações nas relações raciais do Brasil, ver ALBERTO, Paulina L. Terms of inclusion: black intellectuals in twentieth-century Brazil. Chapel Hill, N.C.: The University of North Carolina Press, 2011. 
Franco. Deste, adquiriu a liberdade, herdou o sobrenome e ganhou um lote de terra. A partir de então, fundou em 1882 um dos maiores quilombos brasileiros do século XIX: o quilombo do Jabaquara, na cidade litorânea de Santos, assumindo o papel de liderança negra. Liberdade, igualdade de direitos e perspectivas de um futuro melhor era o que Quintino de Lacerda prometia para os seus "irmãos de cor". Resultado: o Jabaquara cresceu em ritmo acelerado e chegou a abrigar milhares de escravos fugitivos e ex-escravos, significando um importante polo de resistência ao regime de cativeiro na Província de São Paulo. De toda sorte, as sinuosas coligações daquele liberto com o movimento abolicionista, a confraria dos caifazes e com políticos republicanos não foram ainda devidamente elucidadas. Sabe-se que, no contexto imediatamente posterior à Abolição, Quintino de Lacerda se envolveu em episódios controvertidos. Em 1891, por exemplo, aconteceu uma grande greve no porto de Santos. Os trabalhadores eram em sua maioria imigrantes e reivindicavam aumento salarial e melhores condições de trabalho. O clima do movimento ficou tenso até que aquele ex-escravo confabulou-se com o patronato. Assumindo o papel de "fura greves", passou a mobilizar "turmas de homens de cor" para fazer o serviço no lugar dos grevistas. Este e outros posicionamentos ambivalentes e controvertidos - como no da Revolta da Armada, em 1893, quando Quintino de Lacerda ofereceu seu serviço ao governo do Marechal Floriano Peixoto e, por consequência, foi nomeado "major honorário do exército" - não impediram que ele se convertesse em cidadão respeitado pela patuleia e granjeasse cada vez mais prestígio político. Liderança popular e negociadora, ocupou em 1895 o cargo de vereador na Câmara de Santos, chegando a exercer, pelo menos por uma sessão, a presidência da casa. Morreu em 1898 e seu enterro foi bastante concorrido na cidade, com a presença de quase 2.000 pessoas. Aquele líder negro deixou órfãos três filhos, já que sua esposa havia falecido um ano antes, e um legado de lutas e negociações em prol da emancipação, liberdade e ampliação dos direitos. É verdade que nem sempre ele prezou pela coerência, mas as contradições, erros e escolhas infelizes fazem parte da história. ${ }^{3}$

3 Sobre Quintino de Lacerda, ver LANNA, Ana Lúcia Duarte. Uma cidade na 
Aqui fecho o parêntese. Deparar-me com um relato sobre Quintino de Lacerda não foi novidade. Já conhecia pesquisas e livros que discorriam sobre sua trajetória ou o mencionavam. No entanto, nunca tinha ouvido falar de João Mulungu, celebrado por D'Acelino como o mais importante baluarte da resistência negra e luta pela liberdade na história de Sergipe. Senti-me absolutamente intrigado com a narrativa épica que o dirigente do movimento antirracista construiu em torno daquela personagem. Ao final da palestra, um dos professores-coordenadores do Núcleo de Estudos Afro-Brasileiros me apresentou solenemente ao D'Acelino. Conversei rapidamente com ele. Parabenizei-o pela alocução provocadora e lhe fiz uma pergunta, típica de um incauto, sobre João Mulungu. Não me lembro exatamente o teor da pergunta; o que sei é que sua reação foi de aparente espanto com o meu desconhecimento sobre a personagem. Talvez tenha pensado: ora, como esse professor do Departamento de História da UFS não conhece o "Zumbi sergipano"? Pois bem, foi com essa expressão - "Zumbi sergipano" - que ele definiu a importância de João Mulungu para os negros do estado. Senti-me atraído ainda mais pelos significados dessa figura e saí do evento com uma série de dúvidas: qual, afinal, a trajetória de João Mulungu? Será que a aquela narrativa épica em torno dele correspondia aos fatos?

Em outros termos, será que as pesquisas históricas respaldavam o heroísmo daquele negro na luta emancipatória, sua e de seu povo? Ou os atos de heroísmo atribuídos a ele teria sido uma invenção, mas de quem, quando e por quê? Isto não saía de minha cabeça: como teria se dado esse eventual processo de invenção de um herói afro-sergipano? E quais os seus significados? Caí em campo e fui pesquisando autores, obras e agências daqui, compulsando algumas fontes e interlocuções dali, esboçando e amadurecendo uma

transição, Santos (1870-1913). São Paulo/Santos: Editora Hucitec/Prefeitura de Santos, 1991; LIMA, Zózimo. "Quintino de Lacerda". Revista da Academia Sergipana de Letras. Aracaju, n. 12, 1947, pp. 25-29; ROSEMBERG, André. Ordem e burla: processos sociais, justiça e escravidão em Santos, na década de 1880. São Paulo: Alameda, 2006; MACHADO, Maria Helena Pereira Toledo. "De rebeldes a fura-greves: as duas faces da experiência da liberdade dos quilombolas do Jabaquara na Santos da pós-emancipação". In: CUNHA, Olívia Maria Gomes da; GOMES, Flávio dos Santos (orgs.). Quase-cidadão: histórias e antropologias da pós-emancipação no Brasil. Rio de Janeiro: Editora FGV, 2007, pp. 241-282; PEREIRA, Matheus Serva. Uma viagem possível: da escravidão à cidadania. Quintino de Lacerda e as possibilidades de integração dos ex-escravos no Brasil. Niterói, Dissertação (Mestrado em História), Universidade Federal Fluminense (UFF), 2011. 
interpretação dacolá, porém, devido aos meus vários compromissos acadêmicos nos últimos anos, tais perguntas e dúvidas continuaram faiscando no ar. Finalmente, chegou o momento de procurar respondê-las. É escusado dizer que não vai ser possível esgotar um assunto tão complexo e desafiador num único artigo, mas pretendo dar o primeiro passo no sentido de que novas pesquisas aprofundem o que José Murilo de Carvalho já demonstrou: heróis são "símbolos poderosos, encarnações de ideias e aspirações, pontos de referência, fulcros de identificação coletiva". São, por isso, "instrumentos eficazes" para fazer a cabeça e tocar o coração das pessoas em vista da legitimação de projetos dos grupos políticos. Na realidade, não há grupo específico - seja ligado à agremiação partidária, à entidade sindical, ao meio cultural, à religião, à juventude ou às questões de gênero, raça e orientação sexual - que não invente e fomente o culto de seus heróis e não possua seu panteão de ritos e símbolos. Todavia, adverte Carvalho, a "criação de símbolos não é arbitrária, não se faz no vazio social". Herói que se preze tem de ter, de alguma maneira, a cara do grupo que representa. "Tem que responder a alguma necessidade ou aspiração coletiva, refletir algum tipo de personalidade ou de comportamento que corresponda a um modelo coletivamente valorizado". ${ }^{4}$

\section{A invenção do mito}

Eis como tudo começou. No dia 28 de dezembro de 1975, Acrísio Torres publicou na coluna que mantinha na Gazeta de Sergipe ("Pós dos arquivos") um artigo no qual trazia à baila a história da prisão de João Mulungu, o "chefe geral" dos "quilombos" dos municípios de Divina Pastora, Capela, Rosário do Catete, Maruim e Laranjeiras. No período da escravidão, Mulungu, "um líder negro", teria sido o "terror" sobretudo dos "senhores de engenho e 
curraleiros". O "mais famoso e temido calhambola de Sergipe" foi preso em 1876, "no lugar Flor da Roda", em Rosário do Catete, sendo em seguida conduzido à capital da província. Segundo o cronista, Mulungu, "vigoroso nas arremetidas e resistências", mostrou-se "forte na prisão, ante juízes e autoridades". Por isso mesmo, "dissera durante o processo preferir ser enforcado (e foi) na praça pública, a voltar para casa de seu senhor". 5 Parece que, a partir dali, o "mais famoso" quilombola de Sergipe estava fadado a sair dos "pós dos arquivos".

Pelo menos o cineasta Djaldino Mota Moreno leu o artigo e, quando se interessou em filmar a história de Mulungu em super-8, compartilhou-o com Severo D'Acelino, este que é considerado o "fundador" do movimento negro sergipano contemporâneo, pelo seu trabalho à frente tanto do Grupo Regional de Folclore e Arte Cênica Amadorista Castro Alves (GRFACACA), quanto mais tarde do Instituto Sergipano de Pesquisa da Cultura Popular Negra (ISPCPN). ${ }^{6}$ D’Acelino ficou tão impressionado com o que ouvira sobre Mulungu

5 “Mulungu, líder negro". Gazeta de Sergipe. Aracaju, 28 e 29/12/1975, p. 3.

6 A respeito de Severo D'Acelino, ver SILVA, Rosemere Ferreira da. "Severo D'Acelino". In: DUARTE, Eduardo Assis (org.). Literatura e afrodescendência no Brasil: antologia crítica. V. 2. Belo Horizonte: Ed. UFMG, 2011, pp. 293-304. Sobre a importância dessa liderança para a formação do movimento negro contemporâneo em Sergipe, ver o depoimento de Djenal Nobre Cruz - um dos fundadores da União dos Negros de Aracaju, em 1986: "Severo D'Acelino, que era um ator negro e militante, montou o Grupo de Arte Cênica Castro Alves em 1973, a entidade mais antiga doo movimento negro de Sergipe. Em geral, todo mundo do movimento negro passou por essa entidade. Era como se fosse a primeira formação. Foi uma figura de referência para o pessoal que veio depois. Ele trabalhava com poemas, trabalhava com teatro, chamava todo mundo do movimento negro, todo mundo que queria descobrir a cultura negra. Eu acho que ele foi fantástico, porque era uma figura que estava na ditadura militar, em que não se discutia essa questão, e ele dizia: 'Tem racismo nesse país, nesse estado'. In: ALBERTI, Verena e PEREIRA, Amilcar Araujo (orgs.). Histórias do movimento negro no Brasil. Rio de Janeiro: Pallas, CPDOCFGV, 2007, p. 236. Quanto às referências bibliográficas sobre o movimento negro sergipano, consultar OLIVA, Maria de Guadalupe Alves de. Movimento Negro em Sergipe. Revista Movimentos: estudo de teorias e práticas sociais. Aracaju, v. 1, n. 1, 1995, pp. 13-14; NEVES, Paulo Sérgio da Costa. A questão negra em Sergipe: visões de militantes e não-militantes. Trabalho apresentado no XXIV Encontro da ANPOCS (GT: Relações raciais e etnicidade), Caxambu-MG, 2000; _ Luta anti-racista, reconhecimento, redistribuição e cidadania simbólica em Sergipe. In: NEVES, Paulo S. C. e DOMINGUES, Petrônio (orgs.). A diáspora negra em questão: identidades e diversidades étnico-raciais. São Cristóvão: Editora UFS, 2012, pp. 265-301; DANTAS, Paulo Santos. Construção de identidade negra e estratégias de poder: o movimento negro sergipano na década de 1990. Salvador, Dissertação (Mestrado em Ciências Sociais), Universidade Federal da Bahia, 2003; SOUZA, Maria Érica Santana. Movimento negro em Sergipe e política institucional: um estudo a partir da carreira dos militantes negros. Dissertação (Mestrado em Sociologia), Universidade Federal de Sergipe, São Cristóvão-SE, 2012. 
que, apesar de o filme não ter vingado, resolveu tirar aquele líder quilombola do limbo, empreendendo uma campanha de revalorização de sua memória no início dos anos 1980. Para tanto, ele colheu mais dados e informações contidas nos arquivos públicos sergipanos que lhe teriam permitido concluir que Mulungu tratou-se do primeiro herói negro do estado. A partir de 1984, a campanha de divulgação das "proezas" e "façanhas" desse líder quilombola ganhou o espaço público por meio de palestras, cursos de formação, performances teatrais, panfletos, cartazes e artigos publicados na imprensa. ${ }^{7}$

É importante frisar que a revalorização de João Mulungu ocorreu no momento em que o movimento negro brasileiro envidava esforços para alçar Zumbi à condição do primeiro herói negro da nação. Considerado grande guerreiro, líder e mártir do quilombo dos Palmares - tido pelos especialistas como o maior quilombo das Américas -, Zumbi foi apropriado pelo movimento negro contemporâneo como símbolo de resistência escrava e luta contra a opressão racial. Abdias do Nascimento, Lélia Gonzalez, Hamilton Cardoso, Beatriz Nascimento, Joel Rufino dos Santos, entre outras lideranças negras, politizaram e ressignificaram a memória em torno da personagem. De "carne e osso", Zumbi transmutou-se num ícone, sendo lançado ao panteão dos imortais.

Durante a segunda Assembleia Nacional do Movimento Negro Unificado (MNU), realizada no dia 4 de novembro de 1978, em Salvador, foi aprovado o 20 de Novembro - data presumível da morte de Zumbi, em 1695 - como "Dia Nacional da Consciência Negra"; ${ }^{8}$ dois anos depois, um grupo de militantes e intelectuais afro-

7 Entrevista do autor com José Severo dos Santos, em 12/12/2015. Além de ser considerada a liderança mais antiga do movimento em defesa dos direitos dos negros em Sergipe, Severo D'Acelino, como é mais conhecido, é militar reformado da Marinha e poeta, dramaturgo, ator, contista, conferencista e coreógrafo. Dirigiu diversas peças e espetáculos de dança. Interpretou o protagonista de Chico Rei (1985) no cinema e integrou o elenco do filme Espelho d'Á gua (2004) e da minissérie televisiva Theresa Batista, cansada de guerra (1992).

8 Sobre a história do movimento negro brasileiro deste período, com destaque especial ao MNU, ver MAUÉS, Maria Angélica Motta. Da 'branca senhora' ao 'negro herói': a trajetória de um discurso racial. Estudos Afro-Asiáticos, Rio de Janeiro, n. 21, 1991, pp. 119-129; ANDREWS, George R. Black political mobilization in Brazil, 1975-1990. In: George R. Andrews e Herrick Chapman (orgs.). The social construction of democracy, 1870-1990. New York University Press: New York, 1995, p. 218-240; HANCHARD, Michael. Orfeu e o poder: movimento negro no Rio de Janeiro e São Paulo (1945-1988). Rio de Janeiro: EdUERJ, 2001; DAVID, Covin. The Unified Black Movement in Brazil, 1978-2002. Jefferson, NC: McFarland \& Company, 2006; 
brasileiros discutiu em Alagoas a criação do Parque Nacional Zumbi dos Palmares, na Serra da Barriga - local histórico em que existiu o Quilombo dos Palmares; ${ }^{9}$ em 1985, Joel Rufino dos Santos trouxe a público Zumbi, um livro que sedimentou a imagem pública positivada do líder quilombola portador da "utopia emancipatória". ${ }^{10}$ Já em 1986, foi a vez de Hamilton Cardoso publicar um artigo cujo título ("O resgate de Zumbi") sintetizava bem a proposta do autor; ${ }^{11}$ naquele mesmo ano, um monumento para homenagear Zumbi foi erigido no centro do Rio de Janeiro. ${ }^{12}$ No centenário da Abolição em 1988, houve uma grande celebração do "Rei dos Palmares". O movimento negro promoveu no dia 13 de maio daquele ano a "Marcha contra a Farsa da Abolição", no Rio de Janeiro. Numa faixa conduzida, no meio da Marcha, era possível ler as palavras de ordem: "Zumbi vive". Paralelamente, a Pastoral do Negro, um grupo ligado à Igreja Católica, passou a associar a imagem de Zumbi ao Cristo Rei ressuscitado, essa figura messiânica que anunciaria a edificação de novos tempos, de igualdade e fraternidade entre todas as pessoas, negras e brancas. ${ }^{13}$ Do ponto de vista do movimento negro, toda aquela mobilização em torno do símbolo foi coroada de êxito em 1996, quando no governo do presidente Fernando Henrique Cardoso houve o reconhecimento oficial de Zumbi. Seu nome foi inscrito no Livro dos Heróis da Pátria, que se encontra no panteão da liberdade e da democracia (Lei 9.315, de 20/11/96). ${ }^{14}$

DOMINGUES, Petrônio. Movimento negro brasileiro: alguns apontamentos históricos. Tempo, Rio de Janeiro, vol. 12, n. 23, 2007, pp. 100-122.

9 PEREIRA, Amilcar Araujo. $O$ "mundo negro": relações raciais e a constituição do movimento negro contemporâneo no Brasil. Rio de Janeiro: Pallas/Faperj, 2013, p. 272.

10 SANTOS, Joel Rufino. Zumbi. São Paulo: Moderna, 1986.

11 CARDOSO, Hamilton. O resgate de Zumbi. Lua Nova. Cultura e Política, vol. 2, n. 4, 1986, pp. 63-67.

12 CONDURU, Roberto Luís Torres. Zumbi alegórico - o monumento no Rio de Janeiro e outras representações de Zumbi dos Palmares. Pérolas negras - primeiros fios: experiências artísticas e culturais nos fluxos entre África e Brasil. Rio de Janeiro: EdUERJ, 2013, pp. 83-90.

13 BIRMAN, Patrícia. Maio de 88 - outras histórias. In: CONTINS, Marcia (org.). Quase catálogo n. 6: visões da Abolição. Rio de Janeiro: Ciec/ECO/UFRJ/Museu da imagem e do Som/Secretaria de Cultura e Esporte, 1997, pp. 48-72.

14 Ver ainda ANDERSON, Nelson. O mito de Zumbi: implicações culturais para o Brasil e para a diáspora africana. Afro-Ásia, n. 17, 1997, pp. 99-119; FRANÇA, Jean Marcel Carvalho e FERREIRA, Ricardo Alexandre. Três vezes Zumbi: a construção de um herói brasileiro. São Paulo: Três Estrelas, 2012. 
Portanto, foi em sintonia com esse contexto de consagração nacional do "Rei dos Palmares" que, em Sergipe, Severo D'Acelino encabeçou a campanha de disseminação do protagonismo do maior líder quilombola do estado: João Mulungu. No dia 13 de maio de 1985, o jornal A Tarde publicou uma matéria informando que, desde 1981, o GRFACACA-ISPCPN vinha recuperando a memória de Mulungu, "através do cordel, cartaz, palestras (comunicação e divulgação à comunidade), além de seu nome no auditório da entidade". ${ }^{15}$ Em editorial no Jornal Nagô, de 1986, D'Acelino manifestou a importância do "reconhecimento urgente" de um "herói negro sergipano". O nome de Mulungu deveria servir de "exemplo" a todos que propugnava pela construção de uma "sociedade igualitária e mais justa", em especial à comunidade negra, que labutava ora pela resolução de seus problemas, ora pela afirmação de sua identidade. "A comunidade negra sergipana", enfatizava D'Acelino, "deve conhecer os seus heróis, para que através deste comportamento solidifique a sua identidade ancestral". ${ }^{16}$

Não havia unanimidade em torno da campanha. Surgiram críticas, inclusive partindo de setores do movimento negro sergipano, que interpretavam o heroísmo daquele líder quilombola como pura invenção falaciosa de D'Acelino, para fins de autopromoção. ${ }^{17}$ Isto, entretanto, não impediu que a campanha fosse, aos poucos, adquirindo repercussão e respaldo por parte de alguns segmentos da sociedade civil e do poder público, até que, no dia 1 de agosto de 1990, o prefeito da cidade de Laranjeiras, Antônio Carlos Leite Franco, submeteu à apreciação da Câmara de Vereadores o Projeto de Lei, de n. 407, reconhecendo João Mulungu como "Herói Negro", pela "sua real participação e importância na luta contra o cativeiro e na libertação de sua raça no Estado de Sergipe". O Projeto Lei ainda

15 “João Mulungu: herói negro sergipano". A Tarde. Aracaju, 13/05/1985.

16 "Editorial". Jornal Nagô. Órgão oficial de divulgação do Grupo Regional de Folclore e Artes Cênicas Castro Alves - Instituto Severo D’Acelino de Culturas Negras. Boletim Informativo, n. 1, 1986, p. 1.

17 Entrevista do autor com José Pedro dos Santos Neto, em 15/02/2016. Militante histórico do movimento negro sergipano, Pedro Neto foi dirigente da Sociedade Afro-Sergipana de Estudos e Cidadania (SACI) e já assumiu cargos políticos voltados ao combate ao racismo, como o de responsável pela Coordenadoria de Política de Promoção de Igualdade Racial (COPPIR), vinculada à Secretaria Estadual do Trabalho. 
instituía o dia "19 de Janeiro como Dia Municipal de Consciência Negra Laranjeirense", data esta que se referia "à prisão do Líder Negro João Mulungu, nas terras do Engenho Flor da Roda, em Laranjeiras". Submetido à avaliação pela edilidade, o Projeto Lei foi aprovado e sancionado no dia 8 de agosto de $1990,{ }^{18}$ repercutindo positivamente na imprensa local. ${ }^{19}$

O nome daquele líder quilombola saía definitivamente do ostracismo. Em 14 de julho de 1992, cerca de dois anos depois, foi a vez da Câmara Municipal de Aracaju, capital do estado, aprovar e o prefeito Wellington da Mota Paixão sancionar o Projeto de Lei n. 1.858 , que não só reconhecia "João Mulungu como Herói Negro pela sua participação e importância na luta contra a escravidão", como instituía o "19 de janeiro como Dia Municipal da Consciência Negra". ${ }^{20}$ A luta pela construção do mito teve ali um dos marcos mais importante. Ao longo da década de 1990, o GRFACACA-ISPCPN, sempre sob o comando de Severo D'Acelino, continuou difundindo imagens e representações enaltecedoras daquele líder quilombola. Todo aquele trabalho triunfou no dia 5 de outubro 1999, quando a Assembleia Legislativa do Estado de Sergipe, após muita controvérsia, aprovou e o governador Albano do Prado Franco sancionou o Projeto de Lei 132 que, além de recomendar a inclusão do conteúdo da "cultura negra" em concurso público, curso de formação e aperfeiçoamento do servidor público civil e militar, estabelecia o 19 de janeiro como "Dia estadual de luta da consciência negra, em homenagem ao herói negro sergipano, João Mulungú". ${ }^{21} \mathrm{E}$

18 Câmara Municipal de Laranjeiras. Projeto de Lei n. 04/1990. Assunto: Reconhece herói negro de Laranjeiras, institui "Dia Municipal de Consciência Negra Laranjeirense" e dá outras providências correlatas. Autoria: Executivo Municipal. Em aprovado e sancionado, o Projeto deu origem à Lei n. 407, de 08 de agosto de 1990.

19 "Projeto reconhece herói e institui consciência negra". A Voz dos Municípios. Laranjeiras, agosto de 1990.

20 Câmara Municipal de Aracaju. Projeto de Lei n. 19/1992. Assunto: Institui o "Dia Municipal da Consciência Negra" e reconhece João Mulungu como herói negro do município e dá providências correlatas. Autoria: vereador Jorge Araújo. Em aprovado e sancionado, o Projeto deu origem à Lei n. 1.858, de 14 de julho de 1992.

21 Assembleia Legislativa do Estado de Sergipe. Projeto de Lei n. 132/1999. Assunto: Recomenda a inclusão do conteúdo da cultura negra em concurso público, curso de formação e aperfeiçoamento do servidor público civil e militar, e institui o 19 de janeiro como Dia Estadual de Luta da Consciência Negra, e dá outras providências. Autoria: deputada Susana Azevedo. Em 
assim se fabricava o mito. De um líder quilombola negligenciado por décadas pelos desvãos da memória, Mulungu se viu consagrado e alçado ao panteão dos heróis de Sergipe, aliás, até hoje, ele foi a primeira - e única - personalidade negra a ser reconhecida oficialmente como herói do estado.

$\mathrm{Na}$ concepção de Peter Burke, os heróis são "psicologicamente necessários". Algumas pessoas rezam para santos, enquanto outras reverenciam libertadores nacionais, pensadores revolucionários, grandes escritores, cientistas, esportistas e celebridades - como Joana d'Arc, Karl Marx, Che Guevara, William Shakespeare, Albert Einstein, Marilyn Monroe, Elvis Presley, Bob Marley, Ayrton Senna e Michael Jackson -, que continuam sendo objeto de culto décadas ou séculos depois da morte. Heróis e heroínas desse tipo "agem como modelos ou símbolos de nossas identidades ou dos valores de nossa cultura. Ver um indivíduo sob uma luz heroica pode também ser uma expressão de esperanças para o futuro". ${ }^{22}$ Daí o fato de eleitores, em muitos países, "verem geralmente um novo presidente como uma espécie de super-homem ou salvador da pátria, até que o líder comece a se comportar de maneira humana e a desilusão apareça". Para o historiador inglês, o suprimento de heróis "nunca é suficiente para atender à demanda de símbolos religiosos e políticos". Existe um "abismo entre o suprimento e a demanda, como existe entre o ato heroico e a vida heroica". O abismo é vencido por um processo que poderíamos chamar de mitologização. Mito é um termo com muitos significados. "Eu o estou usando aqui", para tomar de empréstimo as palavras de Burke, "para me referir a histórias que uma cultura particular trata como especiais ou até sagradas, que têm um significado simbólico e

aprovado e sancionado, o Projeto deu origem à Lei n. 4.192, de 23 de dezembro de 1999, publicada no Diário Oficial do Estado de Sergipe, em 28/12/1999.

22 Eis como Severo D'Acelino se refere ao assunto em documento distribuído pela Casa de Cultura Afro-Sergipana, entidade que substituiu o GRFACACA a partir de 1986: "O destino dos heróis é a antecipação da utopia; é símbolo e referencial positivo de identificação. A identidade de nós negros sergipanos passa pela revitalização dos nossos símbolos”. Mulungu significa "a ponte do negro do passado ao negro do presente e referencial do futuro, na luta pela plena cidadania e identidade cultural na saga da nossa ancestralidade". D'ACELINO, Severo. "O destino do herói é antecipar a utopia”. Aracaju, s.d. 
nas quais os protagonistas - sejam super-humanos, sejam subumanos - são figuras marcantes". ${ }^{23}$

\section{Entre a história e a historiografia: a desconstrução do mito}

A campanha de reconhecimento de João Mulungu, levada a cabo por Severo D'Acelino e setores do movimento negro sergipano, tinha um caráter eminentemente político, daí a importância de saber: e o mundo acadêmico, da "ciência histórica", tem legitimado o suposto heroísmo dessa liderança quilombola nas hostes pela liberdade, sua e de seus irmãos de infortúnio? Vejamos então o posicionamento dos historiadores especialistas na matéria. Em 1972, José Alipio Goulart publicou um livro no qual aborda "aspectos de rebeldia dos escravos no Brasil". Logo no capítulo inicial, o autor alertava sobre algo: jamais o "negro foi um conformado. Antes, um subjugado; e se como subjugado obedecia, como inconformado reagia". Alipio Goulart não ocultava sua admiração pelas manifestações da resistência escrava, pois estas "revelavam coragem, fortaleza de ânimo, inabalável decisão, indomável espírito de luta, férrea e retilínea vontade". Em sua opinião, "a tudo e a todos o negro enfrentou e afrontou. Nada o detinha quando se dispunha a rebelar-se, posto que mínimas, senão inexistentes, fossem as possibilidades de perene êxito". ${ }^{24}$ Quando se debruça na parte relativa a Sergipe, Goulart assinala que os escravos ali protagonizaram "contínuos levantes", não deixando sossegados os proprietários de engenhos e fazendas. Tais levantes se revestiram de características particulares, neles predominando a tática de guerrilhas. Os quilombolas tinham um espírito ofensivo "surpreendente", atacando estradas, assassinando capitães do mato e feitores;

23 BURKE, Peter. "Introdução: as variedades da biografia". O historiador como colunista: ensaios da Folha. Rio de Janeiro: Civilização Brasileira, 2009, p. 34-35.

24 GOULART, José Alipio. Da fuga ao patíbulo: aspectos de rebeldia do escravo no Brasil. Rio de Janeiro: Conquista/INL, 1972, p. 21. 
recolhendo-se em seguida para o recesso das matas que tão bem conheciam. Para arrematar, o autor transcreve a exposição feita por Vicente de Paula Cascais Teles, quando chefe de polícia da Província de Sergipe Del Rey, e que João Ferreira d'Araújo Pinho, o presidente da província, anexou à sua "fala" no dia 1 de março de 1876 :

Há longos anos são os calhambolas o terror da população do interior. Formando quilombos diferentes, percorrem os engenhos que querem, penetram algumas vezes disfarçados nas cidades, roubam, fazem quantas violências entendem. [...] Agora tenho a satisfação de dizer a V. Ex. que considero extintos os quilombos. O mais forte elemento da resistência, o calhambola João Mulungu, de quem geralmente mais se receava, e todos dizem ser o mais audaz, o chefe dos escravos fugidos, foi capturado no dia 13 de janeiro corrente. [...] Depois de cinco dias e cinco noites de fadigas, da parte do Dr. Juiz Municipal, do Capitão Rocha, do Alferes Marcolino de Sousa Franco e das praças que os acompanhavam, conseguiram a captura do célebre bandido, [que foi conduzido] até esta capital onde tem sido objeto de curiosidade. Pode ter 25 anos mais ou menos, é crioulo, de estatura regular, e como bem qualificaram, um pouco ladino e insinuante, resignado hoje com a sua sorte, preferindo contudo ser enforcado na praça pública a voltar para a casa de seu senhor. ${ }^{25}$

Em 1975, o brazilianist Robert Conrad publicou um livro sobre os últimos anos do regime de cativeiro no Brasil e, no tópico destinado a tratar da resistência dos escravos ("rebeldes e fugitivos"), registra o episódio mais espetacularizado na vida de João Mulungu sua prisão - e reproduz o trecho do relatório do presidente de província que se tornaria clichê: "o calhambola" preferia "ser enforcado na praça pública a ter de regressar para a casa de seu Brasil. Rio de Janeiro: Conquista/INL, 1972, p. 253-254. 
dono". Para Conrad, Mulungu era o "mais arrojado e temido líder fugitivo" de Sergipe, ${ }^{26}$ opinião, por sinal, compartilhada por outros historiadores versados no assunto.

Dois anos depois do brazilianist, Ariosvaldo Figueiredo trouxe a lume uma obra cuja finalidade era perscrutar a história da escravidão em Sergipe pelo vértice da luta de classes. João Mulungu comparece à sua narrativa no capítulo dedicado à "violência e fuga" do cativeiro. $\mathrm{O}$ "chefe quilombola" é caracterizado como valente e o "mais forte elemento da resistência" escrava. Centrado no episódio da captura, Figueiredo compila a famigerada passagem: Mulungu preferia "ser enforcado na praça pública a ter de regressar para a casa de seu dono". ${ }^{27}$ Igualmente procurando examinar os "quilombos e a rebeldia negra" no Brasil à luz dos postulados marxistas, Clóvis Moura publicou em 1981 um opúsculo, no qual faz breve menção a Mulungu. Sem trazer fato novo, cita o relatório que registrou a prisão do "chefe dos escravos fugidos". 28

Quando Lourival Santana Santos investigou a temática da resistência escrava em Sergipe no século XIX, demonstrou como os escravos se rebelaram de diversas formas: fugindo dos engenhos, assassinando feitores, roubando nas estradas, assaltando as grandes propriedades, formando mocambos e quilombos etc. "De todos os quilombolas, o que deu mais trabalho às forças policiais foi o escravo João Mulungu", asseverou o historiador da Universidade Federal de Sergipe. Sua pesquisa - concluída em 1991 - era a que reunia, até então, mais subsídios documentais sobre a trajetória do "Zumbi sergipano". ${ }^{29}$ Visto como o "terror de grande número de proprietários" e gerando dor de cabeça até mesmo no presidente da província, aquele líder quilombola teria atuado em Laranjeiras, Capela, Siriri, Rosário, Itaporanga, Japaratuba, Divina Pastora, entre

26 CONRAD, Robert. Os últimos anos da escravatura no Brasil (1850-1888). $2^{\mathrm{a}}$. ed. Rio de Janeiro: Civilização Brasileira, 1978 [1975], p. 23.

27 FIGUEIREDO, Ariosvaldo. O negro e a violência do branco: o negro em Sergipe. Rio de Janeiro: J. Álvaro, 1977, pp. 90-91.

28 MOURA, Clóvis. Os quilombos e a rebeldia negra. $3^{\text {a }}$. ed. São Paulo: Brasiliense, 1983 [1981], pp. 26-27.

29 Eis como Lourival Santos chega a se referir a João Mulungu num texto de 1988. SANTOS, Lourival Santana. Notas sobre quilombos em Sergipe. Trabalho apresentado no I Ciclo de Debates "Escravidão e Abolição em Sergipe", Aracaju, 10 a 12 de maio de 1988. 
outras localidades, e tecido uma rede de alianças, solidariedade e proteção com moradores dos engenhos e povoados, livres ou cativos, o que the teria permitido se esquivar de diversas diligências impetradas pelas forças policiais. De acordo com Santos, a jornada de insurgência do "Zumbi sergipano" chegou ao fim quando ele foi traído por um de seus coiteiros, o escravo Severino. Dada à importância desse episódio para a construção do mito, vale a pena descortiná-lo aqui. No dia 19 de janeiro de 1876, mais de dez praças, sob o comando do Tenente João Batista da Rocha, dirigiram-se em diligência a Divina Pastora e, chegando ao engenho Vassouras, depararam-se com um escravo de nome Severino, do engenho Flor da Roda, termo de Laranjeiras, que entregou uma carta comunicando que João Mulungu se encontrava nas senzalas do engenho. $O$ delator guiou os soldados até chegar ao engenho Flor da Roda. Como estes não encontraram Mulungu, esconderam-se dentro de um bananal, onde aguardaram novo contato de Severino. Mais tarde, um soldado "disfarçado" - vestindo apenas "camisa, ceroula e chapéu" - saiu para contactar o delator, do qual recebeu a confirmação de que Mulungu se ausentara, mas que retornaria ao meio dia. Por volta das onze horas e meia do dia 20 de janeiro, Severino acorreu até à tropa, dando parte que o temido quilombola se achava descansando com um de seus companheiros no centro do canavial. Incontinenti partiu a tropa e chegando próximo ao local indicado, mandou o Tenente João Batista da Rocha que seis soldados franqueassem pela esquerda, nove pela retaguarda e três atacassem pela frente. Percebendo a tocaia, Mulungu tentou fugir, sendo arrojado no chão com um golpe na cabeça. Preso, foi conduzido a Aracaju, onde teria sido condenado pelos crimes praticados. $^{30}$

A deslealdade do escravo Severino teria sido determinante para a captura de Mulungu. Isto fez com que os cultores do mito se valessem da pesquisa de Lourival Santos para associar a vida de Mulungu a de Zumbi, uma vez que a derrocada do mandatário

30 SANTOS, Lourival Santana. Negros e brancos: uma pedagogia da violência Estudo sobre a resistência escrava em Sergipe no século XIX. Trabalho de aproveitamento do curso de Pós-Graduação em Ciências Sociais, UFS, 1991, pp. 30-32. Deste mesmo autor, ver Quilombos e quilombolas em terras de Sergipe no século XIX. Revista do Instituto Histórico e Geográfico de Sergipe. Aracaju, n. 31, 1992, pp. 31-43. 
palmarino teria sido fruto igualmente de uma "traição". Se até o início da década de 1990 Mulungu vinha sendo retratado pelas pesquisas acadêmicas pelo viés da resistência, com alguns autores produzindo um discurso apologético às ações individuais da personagem, o que serviu de mote para o movimento negro adotá-la como símbolo étnico, a partir dali houve uma inflexão. À medida que Mulungu foi reconhecido oficialmente pelo poder público como herói negro, os trabalhos acadêmicos se empenharam para não só dialogar com o mito, mas desconstruí-lo.

Esta é a tônica de parte da produção historiográfica de Maria Nely Santos. Em artigo de 1995, a estudiosa - professora da Universidade Federal de Sergipe e vinculada ao Núcleo de Estudos Afro-Brasileiros da instituição - rechaçava o título de "super estrela" da resistência escrava atribuído a João Mulungu. Este, de fato, foi "uma das figuras mais populares entre os escravos, um dos personagens temido dos senhores proprietários rurais e um dos mais experientes desafiadores dos cercos policiais", mas daí, afirma Nely Santos, "torná-lo único, ímpar e sobretudo tributar-lhe o título de líder dos quilombolas e herói negro sergipano, é um procedimento no mínimo reducionista". Segundo a historiadora, a "resistência negra em Sergipe" não se esgotou no protagonismo de Mulungu. Apesar de sua captura ter significado o "epílogo de uma trajetória de fugas audaciosas e espetaculares", outros "Mulungus existiram, merecendo cuidadosas pesquisas e análises". Partindo deste pressuposto, a autora investiga os percursos trilhados por Laureano, Frutuoso, Dionísio e Saturnino, quilombolas cujas histórias de transgressão e desafio ao sistema escravista teriam sido silenciadas. ${ }^{31}$ Quando o jornal Universidade Viva publicou uma reportagem especial - intitulada "Herói negro é reavaliado" - e entrevistou Nely Santos, a historiadora não hesitou em expressar o que pensava a respeito daquele "fujão":

João Mulungu, apontado até agora como o maior herói negro de Sergipe, começa a ter o seu papel questionado.

31 SANTOS, Maria Nely. Outros Mulungus, outros mitos? Gbàlà, Sociedade AfroSergipana de Estudos e Cidadania, Aracaju, n. 1, 1995, p. 5. 
Não se pretende apagar sua importância histórica, mas já se combate o mito através de pesquisas como a que vem sendo realizada pela professora Nely Santos, do departamento de história da Universidade Federal de Sergipe. Segundo ela, Mulungu não agiu como "libertador", mas sim como um "fujão" que deu muito trabalho aos donos de engenhos, fazendas e à justiça. Nely Santos aponta outros negros que durante o período da escravidão agiram de forma reconhecidamente heroica e destaca o papel de um branco - Francisco José Alves como o grande abolicionista sergipano. [...] O mito João Mulungu, apontado por alguns pesquisadores e militantes do movimento negro como o maior herói negro de Sergipe, começa a cair por terra. [...] Segundo a professora, criou-se uma série de fantasias em torno dele [...]: "O próprio Mulungu, em um de seus depoimentos chega a afirmar que praticava saques, mas não libertava escravos. A fama que conseguiu expôs demais João Mulungu, que passou a ser acusado por tudo que acontecia, mesmo não tendo qualquer envolvimento". ${ }^{32}$

Em 1997, Nely Santos publicou um livro sobre o movimento abolicionista em Sergipe e, mais uma vez, travou um acerto de contas com o mito João Mulungu: "a história da resistência negra não foi encerrada quando o tenente João Batista da Rocha prendeu João Mulungu, no dia 19 de janeiro de 1876, no canavial do Engenho Flor da Rocha, em Laranjeiras". Influenciada pela visão da "Escola Uspiana", ${ }^{33}$ a historiadora argumenta que o movimento de libertação

32 "Herói negro é reavaliado". Universidade Viva. São Cristóvão, outubro de 1995.

33 Entre as décadas de 1960 e 1970, um grupo de cientistas sociais e historiadores (Florestan Fernandes, Fernando Henrique Cardoso, Otavio Ianni, Emília Viotti da Costa, entre outros) da Universidade de São Paulo (USP) desenvolveram pesquisas que refutavam a ideologia da harmonia racial formulada por Gilberto Freyre, para quem os negros brasileiros, desde a época da escravidão, desfrutariam de mobilidade social e oportunidades de expressão cultural singulares. Os estudiosos da USP acumularam evidências do contrário: os negros teriam sofrido, desde o regime do cativeiro, de intolerâncias, discriminações e "preconceitos de cor" insidiosos. É tanto que a "violência inerente à escravidão havia resultado em anomia ou patologia social entre eles, destruído quase todo o vestígio de sua herança cultural. Impedidos de constituir famílias no cativeiro, tornarase impossível criar formas de cooperação e ajuda mútua que lhes pudesse valer na 'ordem social competitiva emergente"'. Ainda que movido pelo objetivo louvável de denunciar a vigência e 
dos escravos em Sergipe, inclusive aquele liderado por Mulungu, era "espontâneo e desorganizado", por isso a ação quilombola tornou-se incapaz de "subverter a ordem escravista". A "luta dos negros sergipanos pela sua própria organização e características", conclui a autora, "não atingiu um grau de amadurecimento, de consciência coletiva capaz de potencializar todas as camadas da sociedade". ${ }^{34}$ Cerca de uma década mais tarde, Amâncio Cardoso escreveu artigos nos quais reiteravam a assertiva de que, "além de João Mulungu, outros homens lideraram quilombos e também preocuparam autoridades e proprietários" até $1888 .{ }^{35}$

Na sua obra sobre a "escravidão e liberdade" no Vale da Cotinguiba sergipano na segunda metade do século XIX, publicada em 2012, Sharyse Piroupo do Amaral também pauta alguns aspectos biográficos de João Mulungu, sem contudo trazer elementos novos, exceto informar que, após sua prisão, o líder quilombola foi condenado na vila de Rosário do Catete "pelo crime de roubo a um ano de galés, dez açoites e a 'tomar ferro ao pescoço' pelo espaço de um mês". A historiadora soteropolitana infere que a prisão de Mulungu em 1876, embora tivesse sido bastante comemorada pelas autoridades sergipanas, não intimidou a ação de seus companheiros ainda fugitivos. ${ }^{36}$

Em 2015, Igor Fonsêca de Oliveira defendeu tese de doutorado, versando sobre os "quilombos volantes" no Vale da Cotinguiba no século XIX, e reserva um capítulo para ir ao encalço de

abrangência do racismo na sociedade brasileira, tal paradigma interpretativo da "Escola Uspiana" implicou na "desqualificação radical dos escravos como sujeitos possíveis de sua própria história. Em certos casos, apesar do verniz erudito e da aparente sofisticação teórica, o que temos é a [...] 'teoria do escravo-coisa'”, que vê os negros como seres incapazes de ação autônoma e passivos receptores de valores senhoriais. Cf. CHALHOUB, Sidney e SILVA, Fernando Teixeira. Sujeitos no imaginário acadêmico: escravos e trabalhadores na historiografia brasileira desde os anos 1980 . Cadernos AEL, v. 14, n. 26, 2009, pp. 19-20.

34 SANTOS, Maria Nely. A Sociedade Libertadora "Cabana do Pai Thomaz" Francisco José Alves - uma história de vida e outras histórias. Aracaju: Gráfica J. Andrade, 1997, pp. 114, 122, 132.

35 CARDOSO, Amâncio. Escravidão em Sergipe: fugas e quilombos, século XX. Revista do Instituto Histórico e Geográfico de Sergipe, Aracaju, n. 34, 2003-2005, pp. 55-73 e, do mesmo autor, Quilombolas em Sergipe, Séc. XIX. Jornal da Cidade, 13 e 14 de maio de 2007, Opinião, B-9.

36 AMARAL, Sharyse Piroupo do. Um pé calçado outro no chão: liberdade e escravidão em Sergipe (Cotinguiba, 1860-1900). Salvador: EDUFBA; Aracaju: Editora Diário Oficial, 2012, pp. 178-179. 
João Mulungu. Sua tese é, decerto, a pesquisa histórica mais aprofundada e atilada sobre os caminhos e descaminhos trilhados por esse líder quilombola. Filho da escrava Maria e natural do engenho Piedade, da freguesia de Itabaiana, foi vendido ainda pequeno para o senhor João Pinheiro, proprietário do engenho Mulungu, termo de Laranjeiras, daí derivaria o seu sobrenome. Por sofrer maus tratos por parte de João Pinheiro, tentou fugir duas vezes em busca de um novo senhor. Tais tentativas fracassaram, até que, na terceira vez - por volta de 1868 -, a fuga logrou êxito e João Mulungu alcançou a tão sonhada liberdade, dando início à sua vida quilombola entranhado nas matas da Província de Sergipe Del Rey. Logo comandou a construção do primeiro rancho na área do engenho Boa Vista, termo de Capela, convivendo com outros escravos fugitivos. Dali ele e seus companheiros se deslocaram para as matas do engenho Sobrinho e, posteriormente, para as dos engenhos Batinga e Limeira, em Divina Pastora. A esta altura o grupo estava maior: cerca de 20 quilombolas habitavam aquelas matas, juntamente com uma mulher livre. Viviam da prática de furtos (de animais e outros produtos necessários à subsistência nas matas), assaltos nas estradas e saques nas fazendas da região. Com o tempo, Mulungu costurou uma rede de alianças e solidariedades, com livres e assenzalados, negros e brancos, das zonas urbanas e rurais, com os quais negociava ou permutava víveres, armamentos, munições, roupas, ferramentas, informações, relações clientelistas e laços de sociabilidades. Conforme aponta Igor de Oliveira, tão complexas e diversas eram as alianças engendradas por Mulungu que o seu paradeiro constituía, quase sempre, um enigma para autoridades incumbidas de persegui-lo. Pudera. Suas habilidades para operações de deslocamentos súbitos e mobilidades defensivas e de fustigamentos eram notórias. ${ }^{37}$

Desde 1873, ele se tornou o maior alvo das diligências que devassavam as matas do Vale da Cotinguiba. Ou seja, a partir daquele ano, as forças policiais passaram a realizar incursões visando não "lograr a captura de um ou mais escravos fugidos, mas sim, e

37 OLIVEIRA, Igor Fonsêca de. "Por não querer servir ao seu senhor": os quilombos volantes do Vale do Cotinguiba (Sergipe Del Rey, século XIX). Tese (Doutorado em História), Universidade Federal de Pernambuco, Recife, 2015. 
sobretudo, daquele que os dirigiam: o crioulo Mulungu". ${ }^{38}$ As ações audaciosas empreendidas por aquele líder quilombola e seus companheiros ecoavam pelos lugares "mais longínquos do Vale da Cotinguiba, o que elevava não apenas o medo deles, mas também o desejo de vê-los presos". ${ }^{39}$ Por um de seus coiteiros, foi descrito como um "negro" de uma altura "regular", "gordo", vestindo "calça de brim" e usando um "chapéu do Chile na cabeça". Ao que parece, tratava-se de um galanteador, pois se enrabichou com pelo menos quatro amásias - as negras Ana Rita, Vicência e Angélica, além da africana Isabel -, para quais costumava presentear com roupas e outros mimos. Articulando uma espécie de rede familiar, visitava, quando possível, a mãe e a irmã na senzala, momentos nos quais matava a saudade, trocava informações e fortalecia os laços de identidade filial. Quando foi preso em 20 de janeiro 1876 - após cinco dias consecutivos de diligência policial -, tinha entre 25 e 30 anos. Interrogado no calor dos acontecimentos, declarou não ter profissão, visto que era escravo e se encontrava fugido a "mais de oitos anos". Em seguida, foi trazido para a capital Aracaju, como um troféu em exposição pública. Sua prisão foi recebida com euforia e entusiasmo por parte das autoridades públicas, a ponto de Vicente de Paula Teles, o chefe de polícia de Sergipe, informar ao presidente de província que os quilombos estavam "extintos", tendo em vista que o "mais forte elemento de resistência, o calhambola João Mulungu, de quem geralmente mais se receava e todos diziam ser o mais audaz, o chefe dos escravos fugidos, foi capturado". ${ }^{40}$

De acordo com Igor de Oliveira, o nome de Mulungu tornouse rarefeito na documentação consultada a partir de agosto de 1876 , razão pela qual não seria possível indicar o paradeiro daquele líder quilombola: teria ele, realmente, sido morto pelas autoridades, conforme apontaram alguns estudiosos? Ou, após cumprir a pena, acabou sendo reconduzido ao cativeiro no município de Laranjeiras? Seu senhor, assim como muitos outros donos de escravos ladinos das paragens sergipanas, decidiu vendê-lo para o Sul do Império? Com

38 Idem, p. 157.

39 Idem, p. 177.

40 Idem, p. 186. 
relativamente pouca idade, Mulungu alcançou a abolição da escravidão (a Lei Áurea) cerca de 10 anos depois de sua captura? Enfim, como o autor assinala, do ponto de vista da pesquisa histórica, são muitas as questões ainda sem respostas. Quanto ao pretenso heroísmo da personagem, Oliveira é taxativo: "embora apontado como uma liderança, percebemos que a vida de João Mulungu pouco se distinguia" da de outros quilombolas, qual seja, "era mais um escravo que, para manter-se livre e, assim, distante do cativeiro, não se esquivou de usar o arsenal de elementos que então dispunha". ${ }^{41} \mathrm{Na}$ sua opinião, Mulungu não era herói. ${ }^{42}$ Tal como o movimento negro brasileiro fez com o nome de Zumbi, diz ele, "existiram muitos abusos no momento de delinear e sobretudo quantificar os atos perpetrados pelo crioulo João Mulungu". 43

Verifica-se como esta figura legendária tem potencializado um descompasso entre a produção científica e o movimento social ou, antes, entre a narrativa histórica e o discurso politizado da memória, para a qual "os acontecimentos contam muitas vezes menos do que as representações a que dão origem e que os enquadram". ${ }^{44} \mathrm{Se}$, por um lado, setores do movimento negro, capitaneado por Severo

41 Idem, p. 153.

42 Já em sua dissertação de mestrado, concluída em 2010, Igor de Oliveira havia refutado o heroísmo atribuído às ações de Mulungu: "Dou-me por satisfeito se consegui através das histórias narradas e analisadas demonstrar o outro lado deste importante quilombola sergipano. Um lado filho, irmão e amoroso. Não um herói, mas um ser humano. Certamente são estes os fatores que devem ser saudados na identificação [...] entre sua história e a de muitos outros escravos que morreram e sobreviveram alimentando um sonho em comum: a liberdade". OLIVEIRA, Igor Fonsêca de. "Os negros dos matos: trajetórias quilombolas em Sergipe Del Rey (1871-1888). Dissertação (Mestrado em História), Universidade do Estado da Bahia, Santo Antônio de Jesus (BA), 2010, p. 113.

43 OLIVEIRA, Igor Fonsêca de. "Por não querer servir ao seu senhor": os quilombos volantes do Vale do Cotinguiba (Sergipe Del Rey, século XIX). Tese (Doutorado em História), Universidade Federal de Pernambuco, Recife, 2015, p. 154.

44 Sobre o conceito de memória, com seus significados, implicações e diferenças em relação à história, ver LE GOFF, Jacques. História e memória. 5a . ed. Campinas, SP: Ed. da Unicamp, 2003; POLLAK, Michael. "Memória, esquecimento, silêncio". Estudos Históricos, Rio de Janeiro, v. 2, n. 3, 1989, pp. 3-15; _. "Memória e identidade social". Estudos Históricos, Rio de Janeiro, v. 5, n. 10, 1992, pp. 200-212; RICOEUR, Paul. A memória, a história, o esquecimento. Campinas, SP: Ed. da Unicamp, 2007; MENESES, Ulpiano Bezerra de. "A história, cativa da memória? Para um mapeamento da memória no campo das Ciências Sociais". Revista do Instituto de Estudos Brasileiros, São Paulo, n. 34, 1992, pp. 9-23; GUARINELLO, Norberto Luiz. "Memória coletiva e história científica". Revista Brasileira de História. São Paulo, v. 14, n. 28, 1994, pp. 180193. 
D'Acelino, mobilizaram-se para a construção do mito João Mulungu, por outro, a historiografia sergipana, notadamente a mais recente, tem militado pela desconstrução dele. Debalde. Como salienta José Murilo de Carvalho, decerto a preocupação em dialogar com o mito influencia o debate historiográfico; porém transcende tal debate, na medida em que se desenvolve dentro de uma lógica que extravasa os limites e os cânones da historiografia. "O domínio do mito", afirma Carvalho, "é o imaginário que se manifesta na tradição escrita e oral, na produção artística, nos rituais". Isto significa que a "formação do mito pode dar-se contra a evidência documental; o imaginário pode interpretar evidências segundo mecanismos simbólicos que lhe são próprios e que não se enquadram necessariamente na retórica da narrativa histórica". 45

\section{A querela em torno de um símbolo}

Surpreendentemente, a batalha entre a história e a memória acerca de Mulungu igualmente foi travada em outra frente de legitimação cultural: o Conselho Estadual de Cultura de Sergipe. No dia 27 de setembro de 1995, Severo D'Acelino, em nome da Casa de Cultura Afro-Sergipana, protocolou um ofício por meio do qual fazia uma consulta inédita ao Conselho Estadual de Cultura (CEC) - um

45 CARVALHO, José Murilo de. A formação das almas: o imaginário da República no Brasil. São Paulo: Companhia das Letras, 1990, p. 58. Para um conceito de imaginário, ver BACZKO, Bronislaw. Imaginação social. In: Enciclopédia Einaudi. Anthropos-Homem. Lisboa, Imprensa Nacional/Casa da Moeda, v. 5, 1985. Na concepção deste autor, os "imaginários sociais" constituem pontos de referências no vasto sistema simbólico que qualquer coletividade produz e através do qual ela se percebe, compartilha e forma a sua própria "alma". É assim que, por meio dos seus imaginários sociais, "uma coletividade designa a sua identidade; elabora uma certa representação de si; estabelece a distribuição dos papéis e das posições sociais; exprime e impõe crenças comuns; constrói [...] modelos formadores". A vida social "é produtora de valores e normas e, ao mesmo tempo, de sistemas de representações que as fixam e traduzem. Assim se define um código coletivo segundo o qual se exprimem as necessidades e as expectativas, as esperanças e as angústias dos agentes sociais. Por outras palavras, as relações sociais nunca se reduzem aos seus componentes físicos e materiais". O imaginário social é, deste modo, "uma das forças reguladoras da vida coletiva", pp. 7-9. 
órgão consultivo ligado à Secretaria de Estado da Cultura, que tem como uma de suas funções precípuas o pronunciamento quanto à importância dos bens culturais para o tombamento ou registro como Patrimônio Cultural, seja material ou imaterial. Eis os termos da consulta: considerando que a Casa de Cultura Afro-Sergipana há mais de 15 anos vinha desenvolvendo pesquisas com vistas a levantar todos os dados possíveis sobre a trajetória de João Mulungu, o "herói negro sergipano", a fim de melhor referenciar sua luta na resistência negra no estado no segundo quarto do século XIX. Considerando, ainda, que a historiadora Maria Nely vinha sistematicamente promovendo o "linchamento da personagem", "distorcendo e criticando", acusando a Casa de Cultura Afro-Sergipana de plantar um "falso herói" e que aquele quilombola não passava de um "negro fujão etc", Severo D'Acelino solicitava ao "egrégio Conselho" um parecer sobre João Mulungu. ${ }^{46}$

Esse ofício foi o primeiro de uma série de despachos que transformou aquela consulta numa querela em torno do símbolo. $\mathrm{O}$ então Presidente do CEC, Luiz Fernando Soutelo, designou a Conselheira Maria da Glória de Almeida, professora do Departamento de Historia da UFS, como relatora do processo. E requereu, em 27 de outubro, que Severo D'Acelino, o Coordenador Geral da Casa de Cultura Afro-Sergipana, anexasse ao pedido os documentos que declarava possuir sobre João Mulungu, documentos estes que o levaram a concluir ser aquele líder quilombola o "herói libertário do escravo sergipano". ${ }^{47}$ No dia 16 de maio de 1996, D’Acelino respondeu ao Presidente do CEC, assinalando que poderia "custar um pouco" para anexar a documentação requerida. ${ }^{48}$ Tempos depois ocorreu um fato novo: a Conselheira Maria da Glória de Almeida deixou o CEC sem emitir qualquer parecer sobre o processo, o que

46 Processo n. 108/1995/Conselho Estadual de Cultura (CEC). Ofício de José Severo dos Santos, Coordenador Geral da Casa de Cultura Afro-Sergipana, ao Presidente do Conselho Estadual de Cultura. Assunto: Parecer sobre João Mulungu. Aracaju, 25/09/1995.

47 Processo n. 108/95/CEC. Ofício de Luiz Fernando Ribeiro Soutelo, Presidente do Conselho Estadual de Cultura, ao Coordenador Geral da Casa de Cultura Afro-Sergipana. Aracaju, 27/10/1995.

48 Processo n. 108/95/CEC. Ofício de José Severo dos Santos, Coordenador Geral da Casa de Cultura Afro-Sergipana, ao Presidente do Conselho Estadual de Cultura. Aracaju, $16 / 05 / 1996$. 
aumentou as expectativas dos atores envolvidos no pleito. ${ }^{49}$ Em 29 de novembro de 2001, o Presidente do CEC voltou a solicitar a Severo D'Acelino a apresentação, no prazo de trinta dias, dos documentos que comprovassem ser Mulungu o "herói libertário do escravo sergipano". ${ }^{50}$ Não obteve respostas. Nesse ínterim, um novo membro do CEC - Jorge Carvalho do Nascimento, professor do Departamento de História da UFS - foi designado como relator do processo, mas também acabou renunciando ao mandato de Conselheiro sem produzir um parecer. ${ }^{51}$

O caso permanecia indefinido. Quem substituiu Jorge Carvalho do Nascimento no papel de relator foi Pedro dos Santos, um historiador e escritor sergipano. No dia 17 de junho de 2003, este solicitou ao Presidente do CEC que expedisse correspondência à Casa de Cultura Afro-Sergipana, cobrando que o seu Coordenador Geral fizesse juntar ao processo: a) cópia dos requerimentos dirigidos às Câmaras Municipais de Laranjeiras e Aracaju, pedindo o reconhecimento do negro escravo João Mulungu como herói; b) cópia dos decretos municipais que reconheciam o referido negro escravo como herói; c) cópia do requerimento endereçado à Assembleia Legislativa Estadual com o mesmo fim, informando o que a dita Assembleia deliberou sobre tal pretensão. Além disso, Pedro dos Santos solicitava: convidar Maria Nely dos Santos, para que em sessão plenária do CEC externasse sua opinião acerca da figura de João Mulungu, e consultar Lourival Santana Santos, professor do Departamento de História da UFS e um dos estudiosos do assunto, para que, por escrito, comentasse sobre algum "ato de heroísmo ou de bravura" que fizesse do escravo João Mulungu merecedor do título postulado pelo requerente. ${ }^{52}$

49 Processo n. 108/95/CEC. Ofício de Luiz Fernando Ribeiro Soutelo, Presidente do Conselho Estadual de Cultura, a Maria da Glória Santana de Almeida. Aracaju, 11/03/1998.

50 Processo n. 108/95/CEC. Ofício de Luiz Fernando Ribeiro Soutelo, Presidente do Conselho Estadual de Cultura, ao Coordenador Geral da Casa de Cultura Afro-Sergipana. Aracaju, $29 / 11 / 2001$.

51 Processo n. 108/95/CEC. Ofício de Luiz Fernando Ribeiro Soutelo, Presidente do Conselho Estadual de Cultura, a Jorge Carvalho do Nascimento. Aracaju, 10/02/2003.

52 Processo n. 108/95/CEC. Solicitação do Conselheiro Pedro dos Santos a Luiz Fernando Ribeiro Soutelo, Presidente do Conselho Estadual de Cultura. Folha 26, Aracaju, 04/07/2003. 
Severo D'Acelino providenciou a documentação solicitada pelo CEC. Já no que tange a Nely dos Santos, não consta que tenha comparecido à sessão plenária daquele colegiado para manifestar sua opinião sobre João Mulungu. ${ }^{53}$ Postura diferente teve Lourival Santos. No dia 8 de março de 2004, o especialista emitiu um parecer de duas laudas sobre algum "ato de heroísmo ou de bravura" protagonizado por aquele líder quilombola. De acordo com Lourival Santos, "há muito a historiografia tem repudiado toda e qualquer forma de mitificação e heroicização nas suas construções". O estudioso reconhecia a importância de Mulungu para a resistência à escravidão na Cotinguiba, sem contudo heroicizá-lo, mesmo porque, a seu ver, "não existia uma consciência de classe social, não pretendia os escravos rebeldes mudar a estrutura social". Partindo dessa premissa, avaliava que a propositura de Severo D'Acelino, remetida ao CEC, significava uma inversão de valores, isto é, na medida em que se inventava um "negro rebelde" herói, valia-se da mesma estratégia ideológica dos agentes dominantes do passado, convertendo os antigos "heróis", no caso os "senhores brancos civilizados", em vilões. Ao término de seu arrazoado, Lourival Santos declarava se opor à aprovação da heroicização de João Mulungu pelo CEC. ${ }^{54}$

Finalmente, depois de aproximadamente nove anos, um parecer sob a encomenda do CEC foi enunciado sobre aquele líder quilombola. Tudo indicava que a querela chegara a um desfecho, porém não foi o que aconteceu. No dia 18 de janeiro de 2007, um ofício por ordem de José Anderson do Nascimento, o então presidente do CEC, indagava Severo D'Acelino a respeito de seu interesse na continuidade do processo, o que o requerente respondeu positivamente. ${ }^{55}$ A partir daí, um novo relator membro do CEC - José Paulino da Silva, professor aposentado e ex-Vice Reitor da UFS - foi designado. Após examinar os autos, Paulino da Silva deu um parecer em 30 de julho de 2007, referendando a tese de Lourival Santos: "A

53 Entrevista do autor com Pedro dos Santos, em 19/01/2016.

54 Processo n. 108/95/CEC. Parecer de Lourival Santana Santos sobre "algum ato de heroísmo ou de bravura que faça do escravo João Mulungu merecedor do título de herói”, dirigido a Pedro dos Santos, Presidente do Conselho Estadual de Cultura. Aracaju, 08/03/2004.

55 Processo n. 108/95/CEC. Ofício de Ana Luiza Ribeiro Garcez, Secretária Geral do Conselho Estadual de Cultura, ao Coordenador Geral da Casa de Cultura Afro-Sergipana. Aracaju, $18 / 07 / 2007$. 
construção da história não se processa pela relação vilão/herói mas pelas relações sociais do cotidiano através da participação coletiva de pessoas anônimas do povo". Para se pronunciar a respeito do heroísmo ou não de uma personagem de importância histórica como foi João Mulungu, julgava Paulinho da Silva, "é necessário o cotejo de documentação histórica pertinente". No entanto, não existiria nos autos do processo documentos relevantes que dessem ao CEC "argumentos embasados em fatos históricos em prol da heroicização do líder negro João Mulungu". Isto, em sua acepção, não significava negligenciar a importância dos líderes negros que no passado e no presente lutaram e vêm lutando pela justiça, pela liberdade e pela memória de seus ancestrais. "Entendo", concluía o parecerista, "que a maior homenagem que podemos prestar à memória deles, mais do que cultuá-los como heróis, é trazê-los ao conhecimento das novas gerações através do estudo de suas vidas e, sobretudo, inspirar-nos nas mesmas causas pelas quais eles se empenharam: o amor à vida e à luta pela libertação de tudo o que nos oprime". ${ }^{56} \mathrm{Na}$ sessão do dia 7 de agosto de 2007, o CEC deliberou, "por unanimidade de votos e com louvor", pela aprovação do parecer do relator. Com isso, o colegiado de "notáveis" da cultura do estado não chancelava o heroísmo de Mulungu. ${ }^{57}$

Quando a querela parecia ter chegado ao fim, eis que, em 1 de abril de 2008, Severo D'Acelino recorreu da decisão do CEC, sob a justificativa de que a relatoria do conselheiro José Paulino da Silva apresentava equívocos que levaram à "violação de direitos induzindo a discriminações" ${ }^{58} \mathrm{O}$ processo foi recolocado em pauta, em vista de que fosse "distribuído a um novo relator para uma nova avaliação". 59 $\mathrm{E}$, mais uma vez, o CEC deliberou pelo não reconhecimento do heroísmo de Mulungu. ${ }^{60}$ Antes, porém, D’Acelino produziu um

56 Processo n. 108/95/CEC. Parecer do Conselheiro relator José Paulino da Silva sobre João Mulungu. Aracaju, 30/07/2007.

57 Processo n. 108/95/CEC. Deliberação da plenária do Conselho Estadual de Cultura, n. 006/07. Aracaju, 07/08/2007.

58 Processo n. 108/95/CEC. Proposta do Conselheiro José Severo dos Santos ao Conselho Estadual de Cultura, n. 05/08. Aracaju, 01/04/2008.

59 Processo n. 108/95/CEC. Deliberação da plenária do Conselho Estadual de Cultura, $4^{a}$. Sessão ordinária. Aracaju, 06/05/2008.

60 Processo n. 108/95/CEC. Parecer da Conselheira relatora Aglaé d'Ávila Fontes, n. 002/2009. Aracaju, 12/05/2009. 
documento de oito laudas - intitulado "João Mulungu: herói discriminado. Racismo institucional" - para denunciar a "negrofobia instalada no Conselho Estadual de Cultural". De acordo com o Coordenador Geral da Casa de Cultura Afro-Sergipana, os pareceres tanto de Lourival Santos quanto de Paulinho da Silva eram "fraudulentos" e careciam de "verdade". Os "doutos" da UFS teriam desabonado o heroísmo de João Mulungu, mas "não apresentavam os fatos nem os documentos". ${ }^{61}$ Curiosamente, salientava D'Acelino, eles não contestavam os "heróis brancos, só o negro", daí a interpelação: por que não contestavam Caxias e Tiradentes? Um dos pareceristas, Lourival Santos, em especial, era acusado de "modificar constantemente suas afirmações". Num de seus trabalhos teria assinalado: "Podemos considerar João Mulungu como o Zumbi de Sergipe". ${ }^{2}$ De fato, o historiador da UFS foi quem primeiro definiu Mulungu como a versão sergipana do herói negro nacional, o que leva a supor que ele tenha mudado de ideia quando consultado sobre o assunto pelo CEC. Mesmo diante dos protestos do Coordenador Geral da Casa de Cultura Afro-Sergipana, o CEC já havia sentenciado: Mulungu não era herói. De uma vez por todas, o processo foi arquivado.

Nada disso impediu que uma memória social pudesse ser construída em torno daquele quilombola. Suas virtudes foram cantadas em verso e prosa em cordéis, em livros de divulgação e informativos dos movimentos sociais, em manifestações públicas, em leis dos municípios e do estado. Seu nome foi dado a projeto educacional, a grupo de afirmação identitária, a instituições que lutam por direitos civis, a logradouro da cidade, a show musical etc. Conforme argumenta Peter Burke, estudiosos podem "descobrir" que não existe prova confiável para muito do que é dito ou escrito sobre um herói, podem escrever com o intuito deliberado de "desmitologizar ou minimizar aquela personalidade, ou reduzi-la à escala humana comum". Ainda assim, as histórias sobre ela

61 No que concerne aos documentos históricos referentes a Mulungu, o Coordenador Geral da Casa de Cultura Afro-Sergipana alegava que teriam sido "roubados dos arquivos", o que dificultava, se não inviabilizava, o registro da trajetória de vida daquele quilombola.

62 Processo n. 108/95/CEC. "João Mulungu: herói discriminado. Racismo institucional”, de autoria de Severo D'Acelino. Aracaju, s.d. 
continuam a circular. Para o historiador inglês, "parece psicologicamente impossível viver sem heróis, quer os vejamos com olhos críticos, quer não". Pode-se dizer que a "maturidade psicológica é marcada não pela rejeição dos heróis, mas pela capacidade de admirá-los enquanto permanecemos cônscios de suas fraquezas humanas". ${ }^{63}$

\section{$O$ “Zumbi sergipano" sobrevive na memória}

Os mitos conferem sentidos e significados diversos na vida de muitas pessoas. Circulam por intermédio da tradição oral, das manifestações da cultura popular, da mass media, da música, do cinema, da escola, da igreja, do sindicato, das agremiações políticas e culturais e das entidades dos movimentos sociais. Burke entende ser possível mapear o processo de mitologização, o qual geralmente se desencadeia quando algumas pessoas percebem uma semelhança entre as ações de um indivíduo particular - Zumbi, Mandela ou, digamos, Madre Teresa de Calcutá - e um tipo cultural específico, como um libertador, um líder nacional ou um santo que já é alvo de mitos. O estágio seguinte é imputar ao novo herói alguns atributos desse tipo cultural. Se um líder morre em circunstâncias misteriosas, como Emiliano Zapata, no México; o rei D. Sebastião de Portugal, num campo de batalha no Norte da África e porque não dizer João Mulungu, em Sergipe, não raramente surgem comentários de que ele não está realmente morto. Está apenas hibernando, ou preparando o retorno para "levar justiça ao seu povo ou até recuperar o que é percebido como uma era de ouro". ${ }^{64}$

No momento em que saiu a "sentença" do CEC, o sucesso de Mulungu, como herói negro, já havia se cristalizado nos domínios da

63 BURKE, Peter. "Introdução: as variedades da biografia". O historiador como colunista: ensaios da Folha. Rio de Janeiro: Civilização Brasileira, 2009, p. 36.

64 BURKE, Peter. "Introdução: as variedades da biografia". O historiador como colunista: ensaios da Folha. Rio de Janeiro: Civilização Brasileira, 2009, p. 35-36. 
memória. Em 1989, a Câmara de Vereadores de Aracaju aprovou e o Prefeito Wellington da Mota Paixão sancionou uma lei que designava "Largo João Mulungu" o logradouro situado ao fundo do Colégio Francisco Rosa, no bairro Bugio, exatamente na área de acesso à ponte que ligaria aquele conjunto ao bairro Santos Dumont. $\mathrm{Na}$ justificativa do projeto de lei, o vereador Jorge Araújo argumentava que "João Mulungu, em sua trajetória de luta pela libertação de sua raça, foi a ponte de mobilização, ligando de norte a sul toda comunidade negra da província em constante mobilização contra o cativeiro". Mulungu teria sido um "símbolo de resistência contra o cativeiro, e o mais expressivo líder negro em luta na Província de Sergipe". ${ }^{65}$

Antes de o nome daquele quilombola se tornar um "lugar de memória" 66 em Aracaju, a imagem de seu rosto ganhou forma e contornos fisionômicos. Por volta de 1985, Alberto Alcosa - artista plástico e amigo de Severo D'Acelino - produziu uma litogravura para um cartaz em que aparecia o busto de João Mulungu, um negro com corda ao pescoço, barba e cabelos revoltos e olhar no infinito, uma imagem que se assemelhava à famigerada representação pictórica de Tiradentes, o herói da República. Consistia sem dúvida numa idealização. Não existia nenhum retrato de Mulungu feito pelas autoridades que o prenderam nem por quem o tivesse conhecido pessoalmente. O que predominava quando Alcosa fez sua litogravura era a descrição estilizada da figura pelo leitmotiv expressionista, o qual acentuava a simbologia do mártir conduzido ao suplício do patíbulo.

65 Câmara Municipal de Aracaju. Projeto de Lei n. 60/1989. Assunto: Denomina "Largo João Mulungu" e dá providências correlatas. Autoria: vereador Jorge Araújo. Em aprovado e sancionado, o Projeto deu origem à Lei n. 1.517, de 21 de novembro de 1989.

66 Sobre lugares de memórias, ver NORA, Pierre. "Entre memória e história: a problemática dos lugares”. Projeto História, São Paulo, PUC, n. 10, 1993, pp. 7-28. 


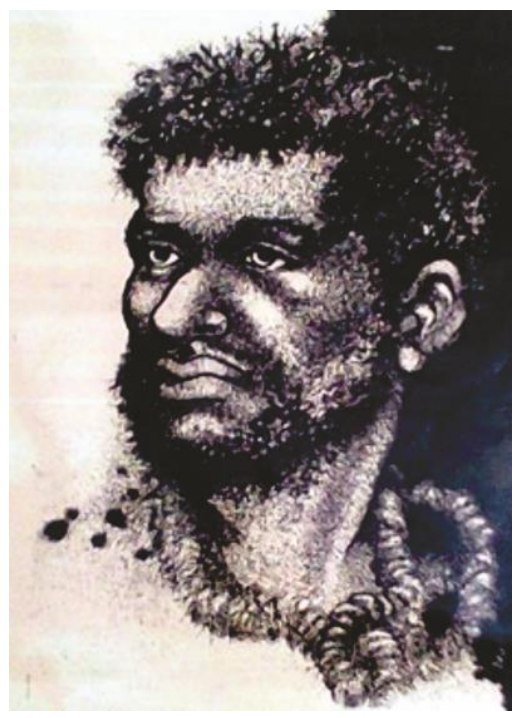

Desde a década de 1990, Severo D'Acelino e o grupo de ativistas que girava na órbita da Casa de Cultura Afro-Sergipana passaram a divulgar, sistematicamente, o nome e a imagem daquele líder quilombola. Por iniciativa desta instituição, em 2002 foi implantado o projeto cultural de educação "João Mulungu vai às escolas", em parceria com a Secretaria de Estado da Educação. Sua inspiração adveio de um projeto similar desenvolvido em São Paulo no governo de Franco Montoro (1983-87), chamado "Zumbi vai às escolas". ${ }^{67}$ No tocante ao projeto sergipano, que percorreu a Capital e várias cidades do interior, buscou difundir a importância do negro na sociedade, com destaque para a história do maior "líder quilombola" do estado, além de promover a discussão sobre o racismo e o antirracismo na educação.

67 BISPO, Denise Maria de Souza. História e cultura afro-brasileira em Sergipe: antecedentes da Lei 10639/03 (1980-2003). São Cristóvão, Dissertação (Mestrado em História), Universidade Federal de Sergipe, 2015, pp. 43-44. 
D’Acelino, especialmente, produziu vários textos volantes (panfletos, manifestos, cartas, moções, artigos etc) de afirmação e celebração de João Mulungu. ${ }^{68}$ Em 2002, ele publicou Panáfrica África Iya N'La, livro que constitui um verdadeiro libelo panafricanista. Nele, o autor louva em panegírico a "saga de João Mulungu". ${ }^{69}$ Dois anos depois, foi a vez de João Mulungu: vida e morte de um negro herói sergipano, opúsculo poético de glorificação do líder quilombola. Mulungu é caracterizado, nesta obra, como um negro "puro e forte", que comandou "os quilombos e os quilombolas", "contra a escravidão", "contra a opressão", "contra a discriminação". "Era o Líder, Herói e Chefe". "Seu nome, seus feitos se espalharam". "Deu a seu povo dignidade". Antes da "morte no patíbulo", ele teria dito:

"Nunca tive a vida

Como contemplação de mim.

Meu povo é minha vida

E ela se multiplica

Onde haja um Negro

Aí eu estou..." A luta continua... ${ }^{70}$

Da perspectiva de D'Acelino, João Mulungu foi um mártir, um paladino de reserva moral, capaz de morrer sem traço de temor, sacrificando-se em prol da libertação de seu povo. Uma versão do opúsculo João Mulungu: vida e morte de um negro herói sergipano

68 D’ACELINO, Severo. “João Mulungu”. Aracaju, s.d; D’ACELINO, Severo. "Manifesto João Mulungu". Aracaju, s.d; D’ACELINO, Severo. "João Mulungu e o modelo afro sergipano". Aracaju, s.d; D’ACELINO, Severo. “Controvérsias sobre João Mulungu”. Aracaju, s.d; D’ACELINO, Severo. "O destino do herói é antecipar a utopia". Aracaju, s.d.

69 D’ACELINO, Severo. Panáfrica África Iya N’La. Aracaju: MemoriAfro, 2002. Sobre a produção cultural do Coordenador Geral da Casa de Cultura Afro-Sergipana, ver SILVA, Rosemere Ferreira da. Afro-descendência em Sergipe: um olhar sobre a produção cultural de Severo D'Acelino. Dissertação (Mestrado em Letras e Linguística), Universidade Federal da Bahia, 2006.

70 D'ACELINO, Severo. João Mulungu: vida e morte de um negro herói sergipano. Aracaju: MemoriAfro, 2004, p. 14. 
foi publicada originalmente sob a forma de cordel. ${ }^{71}$ A propósito, a literatura de cordel dos últimos anos tem feito alusão a essa personagem. $^{72} \mathrm{O}$ fato é que, no decurso do terceiro milênio, o mito Mulungu caiu no gosto popular. É bom ressaltar que os mitos estão, recorrentemente, passando pelo crivo do gosto de seus usuários. Se os atraírem, são consumidos, lembrados e transmitidos; se não atraírem, são descartados, caindo no esquecimento com o tempo. Em 2008, a banda de reggae Oganjah gravou o seu quarto $\mathrm{CD}$, batizando-o com um título bem sugestivo: "Conclamamos João Mulungu". A letra da música, que servia de "carro chefe" do trabalho, enaltecia o "Zumbi sergipano":

Muitos foram eles vieram de lá (da África),

Braçadas sobre o Atlântico empurrados pra cá (de lá pra cá).

Reinos inteiros sendo partidos destrinchados,

Caçados com cães e feitores, execrados, rabujo de cães mal feitores,

Já que não tínhamos armas de fogo não alçaríamos voo de novo,

Mas o fogo de nossas almas é sempre novo mas o fogo de nossas almas arderá de novo,

E de novo conclamamos Zumbi, e de novo conclamamos João Mulungu, Manuel Congo! $!^{73}$

A partir do lançamento do "Conclamamos João Mulungu", a banda montou um show homônimo e se apresentou em palcos da Capital e do interior sergipano, propalando a mística do "herói

71 JOÃO Mulungu: vida e morte de um negro herói sergipano. Aracaju: GRFACACAISPCPN, s.d. Agradeço a José Marciano dos Santos, mais conhecido como Zezé de Boquim, um dos grandes cordelistas de Sergipe, que me indicou e disponibilizou de seu acervo pessoal o cordel cujo enredo enfoca a figura de João Mulungu.

72 Em cordéis que contam a história do estado de Sergipe e da cidade de Laranjeiras, Zé Antônio - cognome de José Antônio dos Santos - verseja estrofes nas quais aparecem João Mulungu. ANTÔNIO, Zé. História e cultura de Laranjeiras - 180 anos. Laranjeiras: Prefeitura Municipal de Laranjeiras, 2012; __ A história de Sergipe decantada em cordel. Aracaju: Edição do Autor, 2013, p. 14: "Liderou os portugueses. Poti chupando caju. E liderou a negrada. O grande João Mulungu. Com a vara da biriba. No Vale do Cotinguiba. Mexendo o seu angu".

73 "Mulungu", de Pablo Ruas/Banda Oganjah. CD Conclamamos João Mulungu. Aracaju: Produção independente, 2008. 
negro". Já a banda Guerreiros Revolucionários, que tem a proposta de levar música, informação e cultura para toda a população, fundou o Instituto de Cultura e Arte João Mulungu (ICAJM) e tem desenvolvido várias atividades relacionadas à cultura e à arte. ${ }^{74} \mathrm{O}$ grupo participou de diversos eventos, dentro e fora de Sergipe, veiculando sua mensagem de engajamento social e valorização da consciência negra centrada no manto do líder quilombola. Desde 2008, a Casa de Cultura Afro-Sergipana disponibiliza na internet o Memorial João Mulungu, com algumas pesquisas acadêmicas, artigos, controvérsias, fontes e imagens que fazem referência ao "Zumbi sergipano". ${ }^{75}$ A fama do mito se espraiou de vez, repercutindo nas instâncias do poder federal. Em 2012, o portal da Fundação Palmares - instituição vinculada ao Ministério da Cultura e voltada à promoção e preservação da cultura afro-brasileira reportou-se ao "legítimo guerreiro" João Mulungu, "o negro que representa as aspirações democráticas do povo de sua raça":

João Mulungu ficou também conhecido como "Zumbi sergipano". Este título se deu por semelhanças com a história do Herói Nacional Zumbi dos Palmares que viveu no Estado de Alagoas dois séculos antes de seu nascimento. Ambos dedicaram suas vidas à mesma causa, lideraram grandes mobilizações, foram perseguidos e assassinados pelos mesmos motivos. ${ }^{76}$

Como se percebe, a nota da Fundação Palmares valia-se da retórica de elevar Mulungu ao mesmo nível de importância, em âmbito estadual, do "herói” Zumbi dos Palmares, em âmbito nacional. Não é de estranhar, assim, que na Caminhada pela Consciência Negra - ato que ocorreu em Aracaju em 2011 e fez parte da programação do Novembro Negro - Zumbi e Mulungu tenham sido rememorados de

74 LIMA, Rodrigo Santos de. Atitudes e percepções na construção de territórios identitários: o bairro Bugio em Aracaju/SE. São Cristóvão, Dissertação (Mestrado em Geografia), Universidade Federal de Sergipe, 2011, pp. 79-80.

75 Ver http://mororialjmulungu.blogspot.com.br/, acesso em 22/01/2016.

76 Ver http://www.palmares.gov.br/?p=17360, acesso em 22/01/2016. 
modo intercambiável. No decorrer do percurso, o professor João Manoel - um dos oradores do ato - discursou contra o racismo na sociedade e evocou a história de João Mulungu, o quilombola que "liderou rebeliões de negros e libertou vários escravos de diferentes municípios sergipanos". Ele também saudou o "herói" Zumbi, que comandou o Quilombo de Palmares. ${ }^{77} \mathrm{O}$ tom laudatório ao "mais importante defensor da causa negra na luta contra a escravidão", que ficou conhecido como o "Zumbi sergipano", também caracterizou a matéria publicada pelo Correio de Sergipe naquele mesmo ano, no Dia Nacional da Consciência Negra. ${ }^{78}$

Durante os festejos de Momo de 2013, o bloco Quilombo - o primeiro bloco afro carnavalesco de Sergipe - desfilou pelas ruas do bairro Santo Antônio, na Capital, trazendo como tema do carnaval "Nordeste: fé no Brasil". Na ocasião, o bloco exaltou o Nordeste brasileiro e colocou em pauta os símbolos da negritude sergipana, como Zumbi, Dandara, Nzinga e, como não poderia faltar, João Mulungu. ${ }^{79}$ Mais do que manter as tradições, o carnaval afrodiaspórico constitui um espaço de criação e redefinição de símbolos, a partir de memórias compartilhadas e postas em circulação. Longe de preservar as sobrevivências, os blocos ditos afro selecionam, ajustam e atualizam as referências, estabelecendo diálogos simbólicos fundamentais para a construção da identidade negra. ${ }^{80}$

No dia 18 de janeiro de 2014, a comunidade remanescente de quilombo de Brejo Grande, município localizado a $137 \mathrm{~km}$ da capital sergipana, realizou um sonho antigo: a construção de uma casa de farinha comunitária. O novo equipamento permite que, além de

77 “Caminhada protesta contra discriminação". Jornal da Cidade. Aracaju, 19/11/2011 (Caderno B1).

$78 \mathrm{Na}$ matéria do Correio de Sergipe, João Mulungu é descrito como um sujeito "esperto e ligeiro. Colaborou com as fugas de milhares de escravos; contudo fortaleceu o contingente de negros em Sergipe. Valente, logo se tornou um líder, um herói, chefe dos quilombolas sergipano e [...] símbolo de luta pela liberdade". Depois de intensas refregas com as forças de repressão, o "herói negro" foi capturado em 1876. Mulungu, consoante o jornal, "preferiu a morte no patíbulo a ter que voltar a viver no cativeiro. A sentença foi proferida; enforcamento em praça pública”. "João Mulungu”. Correio de Sergipe. Aracaju, 20/11/2011, A8. 22/01/2016.

79 Ver http://www.infonet.com.br/carnaval/2013/ler.asp?id=139722, acesso em

80 ALBUQUERQUE, Wlamyra R. O jogo da dissimulação: abolição e cidadania negra no Brasil. São Paulo: Companhia das Letras, 2009, p. 210. 
plantar a mandioca, a comunidade Brejão dos Negros possa processála para transformá-la em farinha e em outros produtos, fomentando a renda familiar e gerando melhores condições de vida para quem vive na localidade. Sua inauguração foi bastante festejada, com direito a fogos, música, dança, capoeira, ritos religiosos e discursos das lideranças quilombolas e dos aliados da causa. Um deles, Thiago Oliveira - presidente do Instituto Braços -, ressaltou que a luta travada pela comunidade não é recente, e teve início lá atrás: "Este domingo é conhecido como o Dia Estadual de Denúncia contra o Racismo por ser o dia da morte do líder da resistência dos negros escravizados em Sergipe, João Mulungu. Como ele, muitos morreram no passado para defender o que hoje estamos começando a colher aqui em Brejão dos Negros", lembrou o advogado. ${ }^{81}$ Decerto, a efígie Mulungu tem conferido sentidos políticos para a mobilização dos quilombolas, de ontem e de hoje.

Quando perguntei a Wellington Fontes Nascimento Coordenador Estadual do Movimento Quilombola de Sergipe - qual o significado que tem João Mulungu para os remanescentes de quilombos e se, de alguma maneira, aquele ícone negro lhe inspira como líder de ações coletivas, a resposta foi bem elucidativa: "A nossa luta não para, teve seu começo no século XIX, mas ainda não temos os nossos direitos garantidos; acho que só muda a forma, os opressores são os mesmos, os fazendeiros, algumas lideranças religiosas e o próprio Estado, que não foi montado para nos ver como pessoas iguais em direitos". Nesse contexto, "João Mulungu tem um significado especial", em razão de sua "luta pelos negros fugidos e sua participação na organização dos quilombos e na defesa do seu povo". Às vezes, nos momentos de dificuldades de nosso movimento, "tento me lembrar da sua ousadia e coragem para enfrentar os obstáculos de frente, sem temer; a sua luta nos inspira em momentos como estes". 82 $22 / 01 / 2016$.

81 Ver http://clicsergipe.com.br/blog.asp?postagem=98485\&tipo=politica, acesso em

82 Entrevista do autor com José Wellington Fontes Nascimento, em 23/01/2016. Morador da cidade sergipana de Estância e ativista dos movimentos sociais há mais de trinta anos, com experiência, por exemplo, na Central dos Movimentos Populares do Brasil, União das Associações de Moradores do Município de Estância, Sindicato dos Trabalhadores nas Indústrias de Sucos, Amidos, Cervejas, Refrigerantes e Afins do Estado de Sergipe, Wellington Nascimento foi 
Em 2015, o Museu da Gente Sergipana prestou uma homenagem a João Mulungu. Na oportunidade, os visitantes tiveram a mediação cultural recheada com informações sobre "um dos maiores líderes da população negra no século XIX", responsável, segundo o release de divulgação, "pela libertação de milhares de escravos no colonialismo". A homenagem culminou com uma roda de capoeira com diferentes mestres, no átrio da instituição. ${ }^{83} \mathrm{O}$ principal museu de Sergipe contribuía, assim, para imortalizar na memória o nome do vulto quilombola. Processo análogo tem ocorrido nas cidades do interior. Em Estância, o movimento em defesa dos direitos dos negros escolhe todo ano alguma personalidade para ser homenageada no dia 20 de novembro; em 2014, o escolhido foi justamente João Mulungu. Durante aquele mês, o homenageado virou tema de palestras nas escolas, nas comunidades quilombolas e na Câmara de Vereadores. ${ }^{84}$ Outras iniciativas são dignas de nota. A União de Negros pela Igualdade (UNEGRO) lançou o "Cine João Mulungu", na sede do Grupo de Capoeira Abaô, com a exibição de filmes que enfocam aspectos da história e cultura afro-diaspórica. Há pouco tempo, assistiu-se a criação do Coletivo João Mulungu, um grupo na rede social facebook formado por pessoas e entidades que desejam discutir e compartilhar informações relacionadas ao "mundo negro". 85

Ao desvelar a trajetória de Malunguinho, que liderou o quilombo do Catucá nos arredores de Recife nas primeiras décadas do século XIX, o historiador Marcus Joaquim Carvalho verificou que o guerreiro quilombola, morto em 1835, recriou-se simbolicamente como divindade da Jurema, sendo ainda hoje cultuado pelos adeptos e simpatizantes desta religião de matriz indígena com influências afrobrasileiras. Os poderes mágicos do "rei das matas" ficariam

um dos fundadores da Associação de Moradores e Amigos Remanescentes de Quilombo do Bairro Porto D'Areia, em 2011, e um dos articuladores da mobilização que resultou na criação do Movimento Quilombola de Sergipe, tendo sido eleito, em 2014, como Coordenador Estadual do movimento.

83 Ver http://www.infonet.com.br/cultura/ler.asp?id=168051, acesso em 22/01/2016. 84 Entrevista do autor com José Wellington Fontes Nascimento, em 23/01/2016. 85 Ver https://www.facebook.com/coletivojoaomulungu, acesso em 22/01/2016. Entrevista do autor com José Pedro dos Santos Neto, em 15/02/2016. 
evidenciados, por exemplo, nos pontos da Jurema. ${ }^{86}$ Consta que João Mulungu também já se metamorfoseou numa entidade da Umbanda, "baixando" em terreiros de Barra dos Coqueiros, cidade da região metropolitana de Aracaju. ${ }^{87}$ "Subir ao panteão das divindades", assevera Carvalho, "é talvez a maior homenagem que um povo pode prestar aos seus heróis". ${ }^{88} \mathrm{Se}$ o "Zumbi sergipano" teve sua vida ceifada por enforcamento no XIX, ele ressuscitou como símbolo, até mesmo espiritual, no século XXI. Será que os seus poderes também são mágicos?

Sabe-se que mulungu (ou mulungum), do gênero erythrina, trata-se de uma árvore de variadas dimensões, com madeira mole e flores grandes, vistosas, vermelhas ou mais raramente alaranjadas, registrada no Brasil desde o primeiro século da colonização. Entrementes, o folclorista Luís da Câmara Cascudo indica que o vocábulo mulungu tem mais de um significado. Consiste numa árvore utilizada na farmacopeia popular. Suas cascas têm o efeito de calmante, peitoral e apressa a maturação de abcessos das gengivas. Mulungu igualmente é usado para se referir a um instrumento musical africano que foi introduzido no Brasil pelos africanos escravizados. Outrossim o termo é empregado para designar o Ser Supremo em vinte e cinco línguas banto, da África Oriental. Esse ser supremo é vulgarmente tido como Criador e associado ao trovão, ao relâmpago e à chuva. ${ }^{89}$

No seu dicionário de língua banto, Nei Lopes define mulungu como uma espécie de ingome, um tambor de origem africana. $\mathrm{O}$ vocábulo também designaria, em várias línguas centro-africanas, o Ser Supremo, correspondente ao Nzambi dos Ambundos e

86 CARVALHO, Marcus Joaquim M. de. O quilombo de Malunguinho, o rei das matas de Pernambuco. In: REIS, João José e GOMES, Flávio dos Santos (orgs.). Liberdade por um fio: história dos quilombos no Brasil. São Paulo: Companhia das Letras, 1996, pp. 407-432.

87 Entrevista do autor com José Severo dos Santos, em 12/12/2015.

88 CARVALHO, Marcus Joaquim M. de. O quilombo de Malunguinho, o rei das matas de Pernambuco. In: REIS, João José e GOMES, Flávio dos Santos (orgs.). Liberdade por um fio: história dos quilombos no Brasil. São Paulo: Companhia das Letras, 1996, p. 428.

89 CASCUDO, Luís da Câmara. Dicionário do folclore brasileiro. 6a. ed. Belo Horizonte: Itatiaia; São Paulo: EDUSP, 1988, p. 513. Sobre Mulungu como o deus supremo dos povos bantos orientais, ver Arthur Ramos. Introdução à antropologia brasileira. Rio de Janeiro: Casa do Estudante do Brasil, 1961 (1º vol. - As culturas não-européias), pp. 343-344. 
Bakongos. ${ }^{90} \mathrm{O}$ caráter sagrado de mulungu se revelou nos cultos afrobrasileiros, os quais usam a planta em seus rituais. Roger Bastide aponta seu emprego no catimbó do Ceará como peitoral, calmante, emoliente e nos candomblés da Bahia é usado nas bronquites e como sedativo das doenças nervosas. ${ }^{91}$ Vista como planta pertencente aos espíritos ancestrais, suas folhas batidas com outras plantas também são empregadas em descarrego, ou seja, em rituais para afastar forças negativas de pessoas ou ambientes. Desse modo, malgrado o termo mulungu não ter sido apropriado do outro lado do Atlântico como sinônimo de "deus todo poderoso", parece-me que o seu sentido mágico-religioso não foi negligenciado.

\author{
João Mulungu \\ Se projeta para liderar a luta \\ Pela reformulação do pensamento \\ A luta com a força de Ogum \\ A Justiça de Shangô, o negro vive \\ Sua cultura, História e Movimento \\ Na glória de sua ancestralidade \\ Na glória de seus heróis resgatados \\ João Mulungun, no panteão brasileiro \\ É um orixá - Ogum do Cotinguiba \\ Toca tambor \\ Toca atabaque \\ Toca agogô \\ Tocando rum \\ Salê filhos de África \\ No shirê para Mulungun \\ Bate palmas \\ Minha gente \\ Samba de satisfação \\ É chegado Mulungun \\ Da Falange de Ogum \\ Ogunhê. ${ }^{92}$
}

90 LOPES, Nei. Novo dicionário banto do Brasil. Rio de Janeiro: Pallas, 1999.

91 BASTIDE, Roger. Sociologia do folclore brasileiro. São Paulo: Anhembi, 1959.

92 D'ACELINO, Severo. João Mulungun: vida e morte de um negro herói sergipano. Aracaju: MemoriAfro, 2004, pp. 15-16. 


\section{As ambiguidades do símbolo}

Além do apelo à metáfora de Zumbi, que facilitou a transmissão da imagem da mártir negro, poder-se-ia perguntar por outras razões da notoriedade de Mulungu como herói afro-sergipano. Pois não tem sido sem resistência que ele atingiu tal status. O líder quilombola tinha (e tem) competidores históricos ao título de herói dos negros sergipanos. Para mencionar os mais óbvios, temos os nomes de Francisco José Alves, Maria do Egito, Beatriz do Nascimento e Quintino de Lacerda. Foi a historiadora Maria Nely Santos quem tentou transformar Francisco José Alves (1825-1896) homem branco natural de Itaporanga, tenente da guarda nacional, excombatente da guerra do Paraguai, fundador da mais importante entidade abolicionista de Sergipe, que, apesar de semianalfabeto, foi editor de dois jornais: $O$ Descrido e o Libertador - em herói da liberdade. Já no início da obra A Sociedade Libertadora "Cabana do Pai Thomaz", Nely Santos explica que uma das motivações para a produção do seu trabalho foi "divulgar para o Brasil e sobremodo para a comunidade afro-brasileira, um pouco da história de Francisco José Alves, defensor incansável dos escravos, na Província de Sergipe". "Idealista, romântico, polêmico, obstinado seriam as principais características deste homem". ${ }^{93}$ Se, por um lado, a autora é refratária ao heroísmo imputado a João Mulungu, por outro, exalta o papel que Francisco José Alves teria desempenhado pela causa da liberdade: "Diante das evidências, não constitui exagero e muito menos qualquer viés de mitificação considerá-lo uma figura ímpar e isolada no contexto histórico abolicionista sergipano". "Na opinião de Santos, os escravos sergipanos até que lutaram pelo fim da escravidão, porém de maneira espontânea e imatura, impulsionando movimentos desprovidos de "consciência coletiva", "coesão" e "planejamento". Nesse sentido, os escravos da província foram incapazes de colocar em xeque a ordem estabelecida, daí o

93 SANTOS, Maria Nely. A Sociedade Libertadora "Cabana do Pai Thomaz" Francisco José Alves - uma história de vida e outras histórias. Aracaju: Gráfica J. Andrade, 1997, pp. $13,163$.

94 Idem, p. 44. 
protagonismo redentor de Francisco José Alves: "se não fora o grito de liberdade do destemido Francisco Alves a favor dos escravos, a sociedade sergipana teria passado à história como uma espectadora silenciosa do movimento abolicionista". ${ }^{95}$ No final da obra, a historiadora volta a carregar na tinta do discurso celebrativo da personagem: se, em termos intelectuais, Francisco Alves não pode ser equiparado a José do Patrocínio, André Rebouças e Joaquim Nabuco, "em termos da coragem, da ousadia e da tenacidade, evidentemente, colocamo-lo no mesmo patamar". ${ }^{96}$

Assim, Francisco José Alves se via entronizado como herói abolicionista. Em que pese todo o esforço de Nely Santos - de desconstruir o mito João Mulungu e, em seu lugar, eleger Francisco Alves como o ícone da liberdade em Sergipe,$-{ }^{97}$ o abolicionista de Itaporanga jamais emplacou no imaginário negro: primeiro, porque era identificado como uma pessoa branca, o que contraria os preceitos racialistas do movimento negro; segundo, porque Francisco Alves manteve escravos e chegou a ser acusado por seus desafetos de libertar os cativos em troca da exploração de seus serviços; por fim, imagens e representações positivadas do abolicionista de Itaporanga não se popularizaram porque ele teria palmilhado o "caminho da moderação" e, digamos, apartado da rebeldia autônoma dos escravos, o que também frustra as expectativas dos ativistas negros contemporâneos. "A impressão que nos deixou", admite a própria Nely Santos, "é de que [Francisco Alves] abominava, reagia e lutava contra a escravidão mas não concordava com os métodos utilizados pelos escravos". 98

95 Idem, p. 78.

96 Idem, p. 168.

97 Na entrevista concedida ao mensário Universidade Viva em 1995, Nely Santos já havia feito apologia às ações empreendidas por Francisco José Alves na luta abolicionista. Talvez tenha sido por isso que o jornal a ele se referiu como "um herói branco", o grande abolicionista sergipano. "Há indícios, segundo Nely Santos, de que Alves libertou mais escravos que o fundo especial criado pela coroa para adotar tal iniciativa. Ele era um homem de caráter, um destemido. Mantinha em sua casa em Aracaju uma escola para alfabetizar os filhos de escravos. 'Francisco Alves realmente lutou pela abolição da escravatura e o seu papel tem que ser reconhecido', comenta". "Herói negro é reavaliado". Universidade Viva. São Cristóvão, outubro de 1995.

98 SANTOS, Maria Nely. A Sociedade Libertadora "Cabana do Pai Thomaz" Francisco José Alves - uma história de vida e outras histórias. Aracaju: Gráfica J. Andrade, 1997, pp. $95-96,78$ 
Maria do Egito era outra competidora. Descoberta pelas pesquisas de Luiz Mott, essa escrava, "mulata", de 30 anos, pertencente ao senhor Evaristo José de Santana, morador de Aracaju, disse em Libelo Cível, de 1858, que seu senhor, homem casado, tiroulhe a virgindade; como recompensa, deu-lhe carta de liberdade e a "teve por sua barregã por mais de 14 anos". Depois, promoveu um casamento de aparência com seu sobrinho. Só que Maria do Egito apareceu grávida do sobrinho. Evaristo Santana teve um surto de ciúmes e, além de espancá-la a ponto de causar-lhe aborto, rasgou a carta de alforria dela. Maria do Egito constituiu advogado e recorreu à justiça, para fazer valer o seu direito à liberdade, mas acabou perdendo a causa e jazendo no cativeiro. ${ }^{99}$

Na década de 1990, Maria do Egito foi apropriada como heroína por um grupo de mulheres negras de Sergipe, que entre 2001 e 2002 fundou a Organização de Mulheres Negras Maria do Egito. Como declarou Joseanes Lima dos Santos, uma das fundadoras da organização, "a história da mulher negra não começou na década de 1990. Ela começou no Estado de Sergipe muito antes e com histórias revolucionárias como a de Maria do Egito. Decidimos pegar essa mulher e trazer para hoje". Qual seja, "a violência contra a mulher negra é de ontem e de hoje. O protagonismo da mulher negra no Estado de Sergipe é de ontem e de hoje". Então "nós trouxemos Maria do Egito, [...] para que as pessoas saibam que essa luta contra o racismo e a discriminação racial não começou por nós, não começou por mim". ${ }^{100}$ Apesar de todo o empenho desse grupo de mulheres afro-sergipanas no trabalho de divulgação da "heroína" Maria do Egito, seu nome ainda é desconhecido e pouco circula no estado, ficando restrito aos nichos das feministas negras.

Problema similar enfrenta Beatriz do Nascimento, outra concorrente de João Mulungu, que mais recentemente entrou no páreo para ocupar o posto de ícone da causa negra sergipana. Maria Beatriz do Nascimento nasceu em Aracaju, em 1942. Ainda criança migrou

99 MOTT, Luiz Roberto de Barros. Escravidão, homossexualidade e demonologia. São Paulo: Ícone, 1988, pp. 66-67.

100 Depoimento de Joseanes Lima dos Santos. In: ALBERTI, Verena e PEREIRA, Amilcar Araujo (orgs.). Histórias do movimento negro no Brasil. Rio de Janeiro: Pallas, CPDOCFGV, 2007, p. 304. 
com a família para a cidade do Rio de Janeiro. Quando adulta, ingressou na faculdade para cursar História, em pleno regime militar. Foi nessa época que passou a se dedicar a uma de suas maiores paixões: a militância a favor dos direitos dos negros. Ajudou a criar o Grupo de Trabalho André Rebouças na Universidade Federal Fluminense, em 1974, e mais tarde manteve vínculos com o Movimento Negro Unificado (MNU), destacando-se como liderança afro-brasileira. Formada, tornou-se professora do ensino fundamental e médio e, posteriormente, universitário. Como intelectual, foi conferencista, participou de eventos acadêmicos, publicou artigos em jornais e revistas especializadas, nos quais explorava temas como relações raciais, mulher negra e a história dos quilombos. No entanto, seu trabalho mais conhecido foi a autoria e narração dos textos do filme Ori, de 1989. O filme é um importante registro dos movimentos negros brasileiros entre 1977 e 1988, abordando as conexões entre Brasil e África e centrado na ideia de quilombo. Em 1986, Beatriz do Nascimento foi premiada com o título Mulher do Ano, pelo Conselho Nacional da Mulher Brasileira. Para mergulhar em profundidade na cultura de seus ancestrais, fez duas viagens à África. Morreu tragicamente em 1995, assassinada com cinco tiros. ${ }^{101}$

Na última década, Beatriz do Nascimento foi "descoberta" pelo movimento de mulheres negras de Sergipe, que tem realizado um trabalho de revalorização de sua memória pelo viés da canonização. Este processo, entretanto, está longe de representar uma ameaça à supremacia simbólica de João Mulungu. Embora tenha se notabilizado na luta contra o racismo e o machismo e seja, por isso, considerada uma referência do movimento negro brasileiro contemporâneo, ${ }^{102}$ Beatriz do Nascimento tem contra si o fato de ter desenvolvido seu ativismo fora de Sergipe; logo, torna-se mais difícil

101 Sobre Beatriz Nascimento, ver RATTS, Alex. Eu sou atlântica: sobre a trajetória de vida de Beatriz Nascimento. São Paulo: Imprensa Oficial/Instituto Kuanza, 2007; CALDWELL, Kia Lilly. Negras in Brazil: re-envisioning black women, citizenship, and the politics of identity. New Brunswick, NJ: Rutgers University Press, 2007; BRITO, Ires Anjos. Revisitando os percursos intelectuais e políticos de Beatriz Nascimento e Lélia Gonzalez. Salvador, Dissertação (Mestrado em Estudos Étnicos e Africanos), CEAO-UFBA, 2012.

102 ROLAND, Edna. O movimento de mulheres negras brasileiras: desafios e perspectivas. In: GUIMARÃES, Antonio Sérgio Alfredo e HUNTLEY, Lynn. Tirando a máscara: ensaios sobre o racismo no Brasil. São Paulo: Paz e Terra, 2000, pp. 237-256. 
difundir imagens e representações positivadas da personagem em seu estado natal, onde os negros geralmente não a conhecem ou se identificam com ela. Seu nome ainda fica circunscrito às plagas das feministas negras.

Quintino de Lacerda era o principal rival. Como já assinalado, este escravo nascido na cidade sergipana de Itabaiana em 1855, e vendido quando jovem para um senhor de São Paulo, labutou com afinco, superou as adversidades até conquistar a liberdade, tornando-se com o tempo líder do quilombo do Jabaquara em Santos, no litoral paulista, como também importante ativista do movimento abolicionista. Desde o seu passamento em 1898, Quintino de Lacerda recebeu várias honrarias de fãs e admiradores, negros e brancos. Em Santos, foi erguido um monumento em seu nome. E, hodierno, o Conselho de Participação e Desenvolvimento da Comunidade Negra da cidade, com apoio da Secretaria de Defesa da Cidadania, promove a cerimônia de entrega da Medalha Quintino de Lacerda, para pessoas que de alguma forma contribuíram para igualdade racial. $\mathrm{O}$ evento marca o Dia Municipal em homenagem a esse liberto. Analogamente, sua memória vem sendo reverenciada em Itabaiana, onde uma importante artéria pública no centro da cidade recebeu o seu nome, assim como o legislativo municipal o reconheceu como "herói negro" em 2001, estabelecendo o dia 8 de junho como dia municipal de luta da consciência negra, em sua homenagem. A despeito de toda a mobilização dos cultores da memória de Quintino de Lacerda em Sergipe, no sentido de colocar em circulação imagens e representações positivadas desse ex-escravo, seu nome permanece associado às hostes pela liberdade em Santos, onde o movimento negro lhe rende tributo de forma ritualizada e o aclamou como um emblema sui generis, quer da luta abolicionista de ontem, quer dos embates antirracistas de hoje.

Um dos fatores que podem ter levado à vitória de João Mulungu é, sem dúvida, o geográfico. Sua trajetória, seus "feitos", suas "proezas", em suma, sua mitologia dialoga com as raízes da experiência negra sergipana. Não é surpresa, assim, que sua apropriação simbólica esteja intimamente relacionada aos dilemas, impasses e desafios da afirmação da negritude no estado. Depõe contra Quintino de Lacerda, igualmente, sua fama de liderança conciliadora, que se envolveu em atitudes contraditórias e 
controvertidas, como a de ter articulado um movimento de "fura greves" no porto de Santos em 1891, ao passo que Mulungu é idealizado como o bastião da liberdade, um dirigente negro guerreiro, intrépido e abnegado, que jamais se curvou às correntes da opressão escravista e teria lutado coerentemente, na base do "sangue, suor e lágrimas", em prol da emancipação, dele e de todo o seu povo.

Parece-me, todavia, que há ainda outro elemento relevante na preferência por Mulungu. É possível que sua vantagem residisse exatamente na mística que envolveu sua morte pretensamente por enforcamento, episódio narrado por diversos historiadores, mas nunca comprovado. Seja como for, o quilombola virou mártir, que teria sacrificado sua vida em prol de uma causa coletiva - a liberdade -, tal como fizera Tiradentes, em nome da República, e Jesus, em nome dos cristãos. O enigma em torno da morte de Mulungu dá margem a interpretações especulativas e imaginações férteis, que vem alimentando a utopia de setores dos movimentos sociais. Mulungu teria morrido como emblema de um sonho, de um ideal nobre e magnânimo. Teria sido vítima não só dos opressores e seus prepostos, mas inclusive de seus amigos. Vítima de traição do escravo Severino, seu companheiro de infortúnio, o abominável Judas. Operava pelo virtual sacrifício, no plano simbólico, a salvação que não pudera se efetivar no mundo real. Tudo isso sensibiliza o imaginário negro. Nessa espécie de auréola arquetípica de Mulungu, todos os afrosergipanos podem se identificar; ele solda a unidade política da cidadania negra, fomenta o ímpeto de participação e união em torno de um ideal: seja a liberdade, no passado; seja a igualdade racial, no presente. Aliás, do ponto de vista de seu significado metafórico, o totem quilombola não separa o presente do passado nem do futuro.

Não obstante, em cada contexto Mulungu tem adquirido diferentes feições. Quando se operou a ressignificação e politização de sua memória na década de 1980, ele era retratado como um herói da resistência negra, ${ }^{103}$ o que muito provavelmente não agradava os setores elitistas e conservadores de Sergipe. Mas na medida em que se

103 Sobre o processo de politização da memória pública da escravidão no espaço Atlântico, ver ARAÚJO, Ana Lúcia. Public memory of slavery: victims and perpetrators in the South Atlantic. Amherst, New York: Cambria Press, 2010. 
afirmava como símbolo étnico, também dividia quando não afastava os setores populares, sem ligação orgânica com a comunidade negra. Atualmente, alguns indicadores apontam para uma conversão do status de herói negro para herói popular. Chegando à reta final desta pesquisa, deparei-me com mais um artigo - publicado n'A Voz dos Municípios, em janeiro de 2016 - que rende tributo a João Mulungu, o "herói negro que cristalizou os anseios de liberdade do povo brasileiro em especial dos sergipanos". ${ }^{104}$ Mulungu é glorificado, em última instância, como herói do povo. O próprio D’Acelino já havia admitido: Mulungu, "marco da resistência negra", simboliza hoje "as aspirações democráticas dos sergipanos, independentemente da raça e/ou posição econômica". ${ }^{105}$ Esse processo de conversão de símbolo étnico para símbolo popular ou democrático ainda está em curso e vem sendo facilitado graças à idealização. Diversos segmentos da sociedade (ativistas, parlamentares, agremiações políticas, sindicalistas, líderes populares, músicos, artistas plásticos, jornalistas, estudantes, professores do ensino fundamental e médio, religiosos ligados à umbanda) passaram a reivindicar ou reinterpretar a herança de Mulungu, procurando adequá-lo a diferentes gostos e matizes. Isto denota a ambiguidade do símbolo. Para muitos, o legendário quilombola não deveria ser visto como herói exclusivo dos negros, mas sim como herói democrático, como mártir, amalgamador, portador da imagem do povo sergipano in totum. Talvez, parafraseando Murilo de Carvalho, o segredo da vitalidade do herói repouse nessa ambiguidade, "em sua resistência aos continuados esforços de esquartejamento de sua memória". ${ }^{106}$

RECEBIDO EM: 02/01/2016 APROVADO EM: 19/04/2016

104 “João Mulungu herói negro nascido em Laranjeiras". A Voz dos Municípios. Laranjeiras, janeiro de 2016, p. 15.

105 D'ACELINO, Severo. "O destino do herói é antecipar a utopia". Aracaju, s.d.

106 CARVALHO, José Murilo de. A formação das almas: o imaginário da República no Brasil. São Paulo: Companhia das Letras, 1990, p. 73. 